\title{
Molecular composition and photochemical lifetimes of brown carbon chromophores in biomass burning organic aerosol
}

\author{
Lauren T. Fleming ${ }^{1}$, Peng Lin ${ }^{2, a}$, James M. Roberts ${ }^{3}$, Vanessa Selimovic ${ }^{4}$, Robert Yokelson ${ }^{4}$, Julia Laskin ${ }^{2}$, \\ Alexander Laskin ${ }^{2}$, and Sergey A. Nizkorodov ${ }^{1}$ \\ ${ }^{1}$ Department of Chemistry, University of California, Irvine, Irvine, CA 92697, USA \\ ${ }^{2}$ Department of Chemistry, Purdue University, West Lafayette, IN 47907, USA \\ ${ }^{3}$ Chemical Sciences Division, Earth System Research Laboratory, National Oceanic and \\ Atmospheric Administration, Boulder, CO 80305, USA \\ ${ }^{4}$ Department of Chemistry, University of Montana, Missoula, MT 59812, USA \\ anow at: California Air Resources Board, El Monte, CA 91731, USA
}

Correspondence: Sergey A. Nizkorodov (nizkorod@uci.edu)

Received: 3 June 2019 - Discussion started: 14 June 2019

Revised: 10 November 2019 - Accepted: 9 December 2019 - Published: 28 January 2020

\begin{abstract}
To better understand the effects of wildfires on air quality and climate, it is important to assess the occurrence of chromophoric compounds in smoke and characterize their optical properties. This study explores the molecular composition of light-absorbing organic aerosol, or brown carbon $(\mathrm{BrC})$, sampled at the Missoula Fire Sciences laboratory as a part of the FIREX Fall 2016 lab intensive. A total of 12 biomass fuels from different plant types were tested, including gymnosperm (coniferous) and angiosperm (flowering) plants and different ecosystem components such as duff, litter, and canopy. Emitted biomass burning organic aerosol (BBOA) particles were collected onto Teflon filters and analyzed offline using high-performance liquid chromatography coupled to a photodiode array spectrophotometer and a highresolution mass spectrometer (HPLC-PDA-HRMS). Separated $\mathrm{BrC}$ chromophores were classified by their retention times, absorption spectra, integrated absorbance in the nearUV and visible spectral range $(300-700 \mathrm{~nm})$, and chemical formulas from the accurate $m / z$ measurements. BrC chromophores were grouped into the following classes and subclasses: lignin-derived products, which include lignin pyrolysis products; distillation products, which include coumarins and flavonoids; nitroaromatics; and polycyclic aromatic hydrocarbons (PAHs). The observed classes and subclasses were common across most fuel types, although specific $\mathrm{BrC}$ chromophores varied based on plant type (gymnosperm or angiosperm) and ecosystem component(s) burned. To study
\end{abstract}

the stability of the observed $\mathrm{BrC}$ compounds with respect to photodegradation, BBOA particle samples were irradiated directly on filters with near UV $(300-400 \mathrm{~nm})$ radiation, followed by extraction and HPLC-PDA-HRMS analysis. Lifetimes of individual $\mathrm{BrC}$ chromophores depended on the fuel type and the corresponding combustion condition. Lignin-derived and flavonoid classes of $\mathrm{BrC}$ generally had the longest lifetimes with respect to UV photodegradation. Moreover, lifetimes for the same type of $\mathrm{BrC}$ chromophores varied depending on biomass fuel and combustion conditions. While individual $\mathrm{BrC}$ chromophores disappeared on a timescale of several days, the overall light absorption by the sample persisted longer, presumably because the condensed-phase photochemical processes converted one set of chromophores into another without complete photobleaching or from undetected $\mathrm{BrC}$ chromophores that photobleached more slowly. To model the effect of $\mathrm{BrC}$ on climate, it is important to understand the change in the overall absorption coefficient with time. We measured the equivalent atmospheric lifetimes of the overall $\mathrm{BrC}$ absorption coefficient, which ranged from 10 to $41 \mathrm{~d}$, with subalpine fir having the shortest lifetime and conifer canopies, i.e., juniper, having the longest lifetime. $\mathrm{BrC}$ emitted from biomass fuel loads encompassing multiple ecosystem components (litter, shrub, canopy) had absorption lifetimes on the lower end of the range. These results indicate that photobleaching of BBOA by condensed-phase photochemistry is relatively slow. Com- 
peting chemical aging mechanisms, such as heterogeneous oxidation by $\mathrm{OH}$, may be more important for controlling the rate of $\mathrm{BrC}$ photobleaching in BBOA.

\section{Introduction}

Forests have naturally occurring wildfire cycles that maintain the forest ecosystem, but global climate change is altering the cycles with unpredictable consequences (Shvidenko and Schepaschenko, 2013; Weber and Stocks, 1998). In addition to the impacts of wildfires on ecosystems, biomass burning plumes have pronounced effects on atmospheric chemistry and climate (Boulanger et al., 2014; Moriondo et al., 2006; Shvidenko and Schepaschenko, 2013; Wotton et al., 2010; Wotton and Flannigan, 1993). Wildfire plumes contain a complex mixture of greenhouse gases (carbon dioxide and methane), multiple non-methane organic compounds (NMOCs), and carbonaceous and ash particles. The effects arising from biomass burning organic aerosol (BBOA) are not well understood because BBOA composition and optical properties may depend on many factors, such as the type of fuel burned and combustion conditions (Chen and Bond, 2010; Jen et al., 2019; Kirchstetter et al., 2004), wind speed, heading or backing fires (Surawski et al., 2015), and fuel moisture content (Tihay-Felicelli et al., 2017). Global climate models are starting to include contributions from lightabsorbing organic carbon, termed brown carbon $(\mathrm{BrC})$, because treating BBOA as purely scattering leads to incorrect predictions of climate forcing (Bond et al., 2011; Laskin et al., 2015; Ma et al., 2012). One of the first studies incorporating $\mathrm{BrC}$ into models was by Feng et al. (2013), who found that in areas where primary $\mathrm{BrC}$ emissions are high the absorbing component of BBOA can dominate over the scattering component, switching net radiative forcing by organic aerosols from negative (cooling) to positive (warming) at the top of the atmosphere. Other modeling studies have demonstrated that $\mathrm{BrC}$ can have large positive effects on the radiative forcing (Bahadur et al., 2012; Chung et al., 2012; Laskin et al., 2015; Ramanathan et al., 2007). However, field measurements to date indicate that $\mathrm{BrC}$ has a short lifetime of $\sim 10 \mathrm{~h}$, which would considerably reduce its impact if included in models (Forrister et al., 2015; Selimovic et al., 2019). Light absorption by $\mathrm{BrC}$ can also result in a significant decrease in the photolysis rates of photochemically active gases, such as $\mathrm{HONO}$ and $\mathrm{NO}_{2}$, which affect the mixing ratios of atmospheric oxidants (Jiang et al., 2012; Li et al., 2011). To better quantify the effect of $\mathrm{BrC}$ on climate, the chemical composition and lifetimes of individual $\mathrm{BrC}$ chromophores, as well as the effect of photochemical aging on the optical properties of $\mathrm{BrC}$ particles, should be studied. Further, for a comprehensive understanding, we should consider the diversity of $\mathrm{BrC}$, spanning nonpolar to polar molecules, and BBOA from a range of sources.
Previous studies have identified important classes of BBOA chemical components that contribute to light absorption. A major class includes lignin-pyrolysis products, which are typically substituted aromatics with a high degree of unsaturation, such as coniferaldehyde (Budisulistiorini et al., 2017; Fleming et al., 2018; Simoneit et al., 1993). Another class is nitroaromatics, such as nitrocatechols, which are readily produced in the presence of $\mathrm{NO}_{x}$ and absorb strongly, with a $\lambda_{\max }$ around $340 \mathrm{~nm}$ (Iinuma et al., 2010; Lin et al., 2017). Polycyclic aromatic hydrocarbons (PAHs) have long been known to be emitted from incomplete combustion processes, and large PAHs can be significantly light-absorbing at the near-UV and visible wavelengths (Simoneit, 2002). Budisulistiorini et al. (2017) observed sulfur-containing species from fern and peat pyrolysis, and suggested that they are formed via acid-catalyzed heterogeneous reactions. Tar balls are largely externally mixed spheres or spherical aggregates produced from smoldering combustion or through multiphase secondary chemistry (Sedlacek et al., 2018; Tóth et al., 2014). In terms of their chemical composition, tar balls are thought be comprised primarily of oxygenated organic compounds, similar to that of BBOA (Chakrabarty et al., 2010; Girotto et al., 2018; Li et al., 2019; Pósfai et al., 2004; Sedlacek et al., 2018).

$\mathrm{BrC}$ components undergo photochemical transformations during atmospheric transport, including photobleaching or photo-enhancement of their absorption coefficients. For example, the field studies of Forrister et al. (2015) and Selimovic et al. (2019) observed a substantial decay in aerosol UV light absorption in biomass burning plumes, corresponding to a half-life of 9 to $15 \mathrm{~h}$. Similarly, Lin et al. (2017) reported rapid evolution of both the BBOA composition and optical properties during a nationwide biomass burning event in Israel. However, there is a recalcitrant fraction of $\mathrm{BrC}$ that persists even after long aging times. Di Lorenzo et al. (2017) found that the fraction of higher-molecular-weight chromophores $(>500 \mathrm{Da})$ relative to lower-molecular-weight chromophores $(<500 \mathrm{Da})$ increased with plume transport time, on the order of hours to days. These changes in BBOA properties are supported by laboratory studies of photochemical aging of BBOA or relevant surrogates via heterogeneous photooxidation (exposure of particles to gaseous $\mathrm{OH}$ and other oxidants), aqueous photooxidation (exposure of BBOA compounds to $\mathrm{OH}$ within cloud/fog water droplets), direct photolysis (exposure of particles or their aqueous extracts to actinic UV radiation), and indirect photolysis (photosensitized reactions between BBOA molecules and electronically excited triplet states of photosensitizers). Several studies have characterized changes in the UV-Vis spectra of nitrophenols, common in BBOA, as they are exposed to UV radiation. For example, Hinks et al. (2016) irradiated 2,4dinitrophenol incorporated in limonene secondary organic aerosol material and observed the absorbance decrease in the range of $250-320 \mathrm{~nm}$, while the absorbance from 400 to $450 \mathrm{~nm}$ increased. Similarly, Zhao et al. (2015) observed 
a photo-enhancement at $420 \mathrm{~nm}$ for a 4-nitrocatechol aqueous solution, in response to direct photolysis. During photooxidation with $\mathrm{OH}$ (produced by an intentional addition of hydrogen peroxide to the photolyzed solution), photoenhancement at $420 \mathrm{~nm}$ was observed initially, but the solution photobleached within an hour. In Hems and Abbatt (2018), aqueous solutions of nitrophenols and hydrogen peroxide were irradiated, atomized, and then analyzed by an aerosol chemical ionization mass spectrometer. This study attributed the photo-enhancement at $420 \mathrm{~nm}$ to the functionalization of nitrophenols, followed by their photodegradation at $420 \mathrm{~nm}$, as was evidenced by fragmentation of functionalized nitrophenols. Lignin pyrolysis products and other ligninderived molecules have been shown to be oxidized into lightabsorbing compounds under certain conditions. For example, Gelencsér et al. (2003) observed an increase in absorption at visible wavelengths during the photooxidation of single-component aromatic hydroxy acids in aqueous solutions. Chang and Thompson (2010) and Tang and Thompson (2012) observed production of light-absorbing compounds during aqueous reactions of $\mathrm{OH}$ with multiple phenolic compounds. Smith et al. (2016) found that triplet-excited molecules can react with phenolic compounds in cloud water and mimic producing $\mathrm{BrC}$ chromophoric products. In Kaur et al. (2019), five model BBOA model compounds were irradiated and hydroxyl radicals, singlet molecular oxygen, and triplet excited-state molecules were detected with probe molecules. They found that all model compounds decayed on the order of hours from indirect photooxidation. There are many studies that have investigated the photodegradation of PAHs on ice surfaces, ocean water mimics, and soil (Smol and Włodarczyk-Makuła, 2017). Shankar et al. (2019) found that the degradation of the three-ring $\mathrm{PAH}$ phenanthrene had a half-life of 13 to $23 \mathrm{~h}$ depending on the solvent it was dissolved in. Using infrared spectroscopy they observed the emergence of carboxylic acid, aldehyde, and ketone functionalities during photolysis. Miller and Olejnik (2001) irradiated aqueous solutions of PAH mixtures with UVC lamps. They found that the photodegradation of benzo[ $a]$ pyrene and chrysene proceeds more rapidly at acidic $\mathrm{pH}$ values and proposed a mechanism based on their findings.

The photochemical aging of actual mixtures of BBOA compounds, not just surrogates, was also reported in the literature. For example, Tomaz et al. (2018) found that aqueous BBOA mixtures from the 2016 FIREX lab intensive decayed rapidly, with most having lifetimes due to aqueous $\mathrm{OH}$ oxidation mimicking clouds of a half a day or less. The decay of compounds such as catechol, benzoic acid, and methylfurfural lead to the formation of oxalate, which made up $13 \%-$ $16 \%$ of total dissolved organic carbon after $150 \mathrm{~h}$. Saleh et al. (2013) burned pocosin pine and oak, and diluted smoke was irradiated with UV lights in a smog chamber. Aerosol optical properties were monitored with an aethalometer at seven wavelengths. They found that aged emissions were more absorbing than fresh emissions at 370 and $470 \mathrm{~nm}$ af- ter $1 \mathrm{~h}$. Zhong and Jang (2014) tracked the absorption coefficients of BBOA during solar exposure in a smog chamber, and observed an increase of $11 \%-54 \%$ in the integrated mass absorption cross section $(280-600 \mathrm{~nm})$ in the first half of the day, followed by decrease in the afternoon. In Lin et al. (2016), BBOA collected from ponderosa pine and Indonesian peat burns were dissolved in a $50 \%$ by volume water/acetonitrile solvent and irradiated with actinic wavelengths. They found that, regardless of the fuel type, the half-life of the absorbance at $300 \mathrm{~nm}$ was roughly $16 \mathrm{~h}$ under sunlight for soluble BBOA. Wong et al. (2017) found that irradiated BBOA water extracts lost water-soluble organic carbon (WSOC) when irradiated with 300-400 nm light. Simultaneously, the absorption coefficients at 365 and $400 \mathrm{~nm}$ first increased, in the latter case to about $0.035 \mathrm{~m}^{2} \mathrm{~g}^{-1}$ after $20 \mathrm{~min}$ of illumination time, and then decreased to nearly 0 in $60 \mathrm{~min}$. Size-exclusion chromatography showed that low-molecular-weight $\mathrm{BrC}$ chromophores (<400 Da) were quickly formed and photo-degraded, giving yield to a photo-enhancement due to the formation of high-molecularweight species ( $>400 \mathrm{Da}$ ). They concluded that this highmolecular-weight fraction was responsible for long-lived light absorption. In Sumlin et al. (2017), BBOA produced from burning Alaskan peat were aged by reactions with $\mathrm{OH}$ in an oxidation flow reactor (OFR), and light absorption coefficients of aged and unaged BBOA were measured by an integrated photoacoustic nephelometer. They found that the mass absorption coefficient at $375 \mathrm{~nm}$ deceased roughly $45 \%$ after an equivalent of $4.5 \mathrm{~d}$ of photochemical aging.

To summarize the literature survey above, much work has been done in terms of characterizing optical properties of photochemically aged BBOA and surrogates, but a consensus on what drives the photobleaching and photo-enhancement of chromophores in BBOA and the relative importance of these processes on atmospherically relevant timescales has not been reached. This study aims to better understand the molecular composition of $\mathrm{BrC}$ for different fuel types and combustion conditions as it may be essential to understanding the optical properties of BBOA and predicting their evolution during photochemical aging.

This study explored the diversity in the molecular composition of BrC chromophores found in BBOA samples generated by burning forest fire fuels, and examined how the chemical composition and optical properties change during UV irradiation of $\mathrm{BrC}$ materials in the absence of gas-phase oxidants. BBOA samples from 12 biomass fuels collected from around the United States, encompassing both gymnosperm and angiosperm plant types and different parts of the ecosystem, including duff, litter and canopy, were examined. Samples collected on filters were extracted by a mixture of dichloromethane, acetonitrile, and hexanes and analyzed by high-performance liquid chromatography coupled to a photodiode array spectrophotometer and a highresolution mass spectrometer (HPLC-PDA-HRMS) to target $\mathrm{BrC}$ chromophores. To investigate whether the $\mathrm{BrC}$ chro- 
mophores are photolabile or photostable, BBOA particle samples were directly irradiated on filter substrates before analysis by HPLC-PDA-HRMS or UV-Vis spectrometry. We estimated their lifetimes in BBOA under UV-irradiated conditions by measuring the time-resolved absorbance of individual chromophores. We found that the equivalent atmospheric lifetime for photochemical transformations of individual chromophores ranged from 0.4 to $1.6 \mathrm{~d}$, which is a relevant timescale for long-range atmospheric transport. $\mathrm{BrC}$ chromophores could survive the exposure to UV radiation on different timescales, depending on their molecular structure or their interactions with neighboring molecules dictated by BBOA type. However, the overall absorption by $\mathrm{BrC}$ (integrated over 300-700 nm) persisted longer under UV irradiation, with lifetimes ranging from 10 to $41 \mathrm{~d}$, presumably because products of the condensed-phase photochemical reactions of the original $\mathrm{BrC}$ chromophores are also light-absorbing. The equivalent atmospheric lifetimes of $\mathrm{BrC}$ absorption under UV irradiation are long in comparison to typical lifetimes for heterogeneous oxidation of BBOA by $\mathrm{OH}$. For climate modeling applications, these results suggest that chemical aging mechanisms other than condensed-phase photochemistry may play a more significant role in the evolution of the BrC optical properties.

\section{Experimental methods}

\subsection{Sample collection and information}

BBOA particle samples were collected during the FIREX Fall 2016 lab intensive at the Missoula Fire Lab (https: //www.esrl.noaa.gov/csd/projects/firex/firelab/, last access: 1 May 2019). One of the BBOA samples used in this study was from a "stack" burn and the other samples were from "room" burns. Selimovic et al. (2018) explains room and stack burns and fuels in detail. Briefly, the combustion of forest fire fuels lasted 5-20 min and during stack burns emissions were collected from a constant, diluted flow of entrained emissions by way of the stack. In room burns, the smoke from the fire was allowed to mix in the room during sample collection, and BBOA was collected during both the burn and mixing periods. Smoke was purged from the room by clean air between burns. Fuels were collected from different US regions and brought to the Missoula Fire Lab for test burns. This paper focuses on 12 fires covering gymnosperm or conifers, including ponderosa pine (Pinus ponderosa), lodgepole pine (Pinus contorta), Engelmann spruce (Picea engelmannii), Douglas fir (Pseudotsuga menziesii), juniper (Juniperus), longleaf pine (Pinus palustris), and subalpine fir (Abies lasiocarpa). Angiosperm forest fire fuels included Montana sagebrush and two types of chaparral, i.e., manzanita (Arctostaphylos) and chamise (Adenostoma fasciculatum). In some test burns, a representative "ecosystem" mix of biomass was used, including canopy, duff, litter, herbaceous, and shrub components. In other test burns, single biomass components of the ecosystem were used, such as rotten log samples. Information for each fire is provided in Table S1 in the Supplement.

Copper tubing with a $\mathrm{PM}_{2.5}$ cyclone inlet was placed in the combustion room, while the pump and filter were located in an adjacent room. The pump was operating at a flow of $16.7 \mathrm{~L} \mathrm{~min}^{-1}$ with the aid of a critical orifice, and BBOA particle samples were collected on PTFE filter substrates (FGLP04700, Millipore, $47 \mathrm{~mm}$ diameter, $0.2 \mu \mathrm{m}$ pore size) during both of the combustion and smoke-mixing stages of the room burns. Loaded filters were stored at $-18^{\circ} \mathrm{C}$ until they were analyzed for $\mathrm{BrC}$ chromophores no more than 2 months after sampling. The room burn protocols allowed for long collection times and therefore higher aerosol mass loading, which is desirable for the analysis described below.

\subsection{HPLC-PDA-HRMS}

The molecular identity and relative abundance of $\mathrm{BrC}$ chromophores were determined using the HPLC-PDAHRMS platform described by Fleming et al. (2018) and Lin et al. (2018). Segments of the filter were extracted into a mixture of organic solvents composed of $2.0 \mathrm{~mL}$ dichloromethane, $2.0 \mathrm{~mL}$ acetonitrile, and $1.0 \mathrm{~mL}$ of hexanes, which was shown to optimize the extraction efficiency (Lin et al., 2017). The extraction occurred overnight on a platform shaker. Extracts were filtered with polyvinylidene fluoride (PVDF) syringe filters (Millipore, Duropore, $13 \mathrm{~mm}$, $0.22 \mu \mathrm{m})$ to remove undissolved suspended particles. Water $(50 \mu \mathrm{L})$ and dimethyl sulfoxide (DMSO; $100 \mu \mathrm{L})$ were added to the extracts, which were then concentrated under a flow of $\mathrm{N}_{2}$ until the volume was reduced to roughly $150 \mu \mathrm{L}$, which signified that the extracting solvent evaporated and (mostly) water and DMSO remained in the solution. For photolyzed BBOA, DMSO $(30 \mu \mathrm{L})$ was exclusively added to the extract, and evaporated to a volume of $30 \mu \mathrm{L}$. Visual inspection confirmed that the extracted material did not precipitate out of solution.

The HPLC utilized a reverse-phase column (Luna C18, $2 \times 150 \mathrm{~mm}, 5 \mu \mathrm{m}$ particles, $100 \AA$ pore size, Phenomenex, Inc.). The injection volume was $5.0 \mu \mathrm{L}$ for unphotolyzed or $10 \mu \mathrm{L}$ for extractions of post-irradiated samples, with the latter providing more analyte mass since only a quarter of the filter was used in irradiation experiments. The mobile phase consisted of $0.05 \%$ formic acid in liquid chromatographymass spectrometry (LC-MS) grade water (A) and LC-MS grade acetonitrile (B). Gradient elution was performed with the A-B mixture at a flow rate of $200 \mu \mathrm{L} \mathrm{min}^{-1}: 0-3 \mathrm{~min}$ hold at $90 \%$ A, 3-62 min linear gradient to $10 \%$ A, 6375 min hold at $10 \% \mathrm{~A}, 76-89$ min linear gradient to $0 \% \mathrm{~A}$, 90-100 min hold at $0 \% \mathrm{~A}$, then 101-120 min hold at $90 \%$ A. The electrospray ionization (ESI) settings of the Orbitrap HRMS were as follows: $4.0 \mathrm{kV}$ spray potential, 35 units of sheath gas flow, 10 units of auxiliary gas flow, and 8 units of 
sweep gas flow. The solutions were analyzed in both positive and negative ion ESI-HRMS modes.

The HPLC-PDA-HRMS data were acquired and first analyzed using Xcalibur 2.4 software (Thermo Scientific). Possible exact masses were identified based on the corresponding LC retention time using the open-source software toolbox MZmine version 2.23 (http://mzmine.github.io/, last access: 28 July 2017) (Pluskal et al., 2010). Chemical formulas were assigned from exact $m / z$ values using the Formula Calculator v1.1. More details about experimental procedures and data processing can be found elsewhere (Lin et al., 2015b, 2016, 2018).

\subsection{Condensed-phase photochemistry experiments}

A quarter of the filter was directly irradiated by either an ultraviolet light-emitting diode (LED, Thorlabs M300L4) or a filtered xenon arc lamp. The LED was used in experiments aimed at estimating lifetimes of individual chromophores. The LED emission spectrum was centered at $300 \mathrm{~nm}$ with a full width at half maximum (FWHM) of $20 \mathrm{~nm}$. This wavelength was chosen because it corresponds to the most energetic UV photons available in the lower troposphere. It is common practice in photochemical experiments to use narrow band UV sources, as opposed to a broadband simulator, as it limits sample heating and evaporation (Calvert and Pitts, 1966). The LED was fixed half a centimeter away from the filter, resulting in an incident power density of $11 \mathrm{~mW} \mathrm{~cm}^{-2}$. Irradiation times for these experiments are given in Table S2. After the irradiation step, the photolyzed BBOA were extracted and analyzed using HPLC-PDA-HRMS as described in the previous section.

The irradiation time using the LED was converted into an equivalent time under sunlight by calculating the ratio of the 290-350 nm integrated spectral flux of the Sun and the $300 \mathrm{~nm}$ LED, given in Eq. (1). This conversion assumes that photochemistry is limited to the $<350 \mathrm{~nm}$ range, consistent with the photochemistry of many organic molecules, which exhibit a sharp drop in the photochemical quantum yields at longer wavelengths (Turro et al., 2009). Because the radiation source does not replicate the solar spectrum, the lifetimes calculated from the formula below should be regarded as estimates.

$\tau_{\text {atm }}=\tau_{\text {LED }} \times \frac{\int_{290 \mathrm{~nm}}^{350 \mathrm{~nm}} F_{\mathrm{LED}}(\lambda) \mathrm{d} \lambda}{\int_{290 \mathrm{~nm}}^{350 \mathrm{~nm}}\left\langle F_{\text {solar }}(\lambda)\right\rangle_{24 \mathrm{~h}} \mathrm{~d} \lambda}$

The spectral flux density for the LED and the Sun as a function of wavelength is shown in Fig. 1. The solar flux density was estimated every hour and averaged over a $24 \mathrm{~h}$ period for Los Angeles, CA ( $\left.34^{\circ} \mathrm{N}, 118^{\circ} \mathrm{W}\right)$, on 20 June 2017 from the quick Tropospheric Ultraviolet Visible (TUV) calculator (Madronich et al., 2002) using the following parameters: $300 \mathrm{DU}$ overhead ozone column, 0.1 surface albedo $(0-1)$, and ground elevation of $0 \mathrm{~km}$ with default outputs for

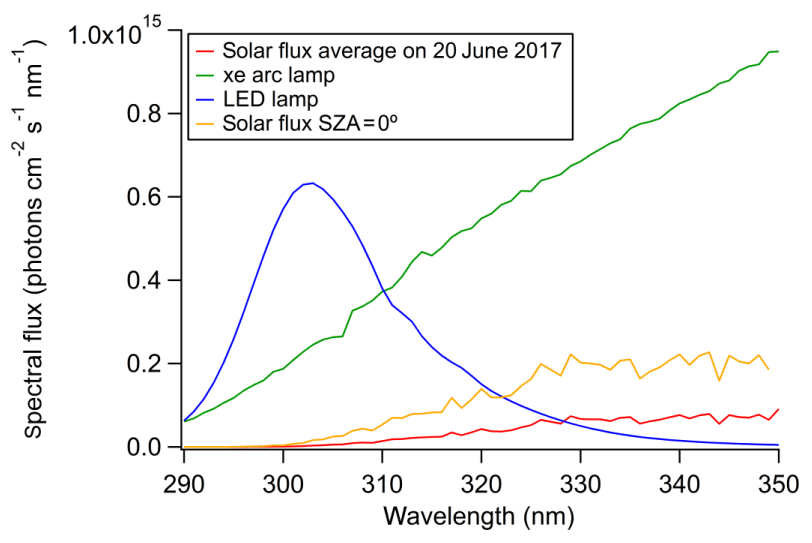

Figure 1. Spectral flux density (photons $\mathrm{cm}^{-2} \mathrm{~s}^{-1} \mathrm{~nm}^{-1}$ ) approximated for a solar zenith angle of $0^{\circ}$ (orange), as well as the $24 \mathrm{~h}$ average for the latitude and longitude of Los Angeles $\left(34^{\circ} \mathrm{N}, 118^{\circ} \mathrm{W}\right)$ on 20 June 2017 (red). The spectral flux density for the $300 \mathrm{~nm}$ LED (blue) and the filtered Xe arc lamp (green) are also shown.

aerosols and clouds. The procedure for calculating the spectral flux density of the LED is described in the Supplement. The maximum possible spectral flux density from the Sun was also calculated at a solar zenith angle (SZA) of $0^{\circ}$ using the TUV calculator. The equation for calculating the equivalent atmospheric lifetime at an SZA of $0^{\circ}$ is the same as Eq. (1), except that the $24 \mathrm{~h}$ averaged flux density is replaced by the peak flux density at $\mathrm{SZA}=0$. The $\mathrm{SZA}=0^{\circ}$ comparison represents the lower limit of $\mathrm{BrC}$ absorption lifetimes.

In a separate series of experiments, filter samples were irradiated by the filtered radiation from a xenon arc lamp to determine the characteristic lifetime for the photobleaching of the overall absorption by $\mathrm{BrC}$ molecules. A quarter of a PTFE filter sample was exposed to filtered light emitted from a xenon arc lamp (Newport 66902). Broadband light was reflected at a $90^{\circ}$ angle using a dichroic mirror, then filtered through a $295 \mathrm{~nm}$ long-pass filter (Schott WG295), and finally passed through a UV bandpass filter (Schott BG1), ultimately transmitting light in the range of $290-400 \mathrm{~nm}$. The incident overall power density was $196 \mathrm{~mW} \mathrm{~cm}^{-2}$. Particles were irradiated for $\sim 12 \mathrm{~h}$ to $1.8 \mathrm{~d}$; the exact time varied from sample to sample depending on the offline transmission spectra. Transmission spectra were acquired directly from the PTFE filter without any material extraction using a Jasco V-670 absorption spectrometer, with a blank PTFE filter used as a reference. Four to six transmission spectra were collected at each time point as the filter was rotated, to minimize the effect of the filter orientation. The filter was then returned to the irradiation setup for further irradiation. When there was no longer any change in the transmission spectrum due to irradiation, the filter was extracted into an organic solvent mixture of $10 \mathrm{~mL}$ methanol, $5.0 \mathrm{~mL}$ acetonitrile, and $2.0 \mathrm{~mL}$ of hexane in a scintillation vial using a vortex mixer. While dichloromethane would be a better solvent for BBOA material, methanol was used for these experi- 
ments, since dichloromethane absorbs at longer wavelengths in the UV (up to $240 \mathrm{~nm}$ ) and could interfere with the measurement. The solution was then evaporated down to $5 \mathrm{~mL}$ in order to increase the analyte concentration. For comparison, an un-irradiated quarter of the filter was prepared identically in a separate vial, and solution-phase transmission spectra of both solutions were recorded using a dual beam UV-Vis spectrometer (Shimadzu UV-2450). Sample filter-based and solution-phase spectra are shown in Fig. S2, with the $y$ axis converted to effective base-10 absorbance, $A=-\log (T)$, where $T$ is the wavelength-dependent transmittance through the filter or the cuvette. For filter-based transmission spectra, the baseline was manually corrected by assuming the absorbance at $850 \mathrm{~nm}$ was zero for $\mathrm{BrC}$.

In all UV irradiation experiments, the integrated absorbance from 300 to $700 \mathrm{~nm}$ was calculated and normalized to the starting integrated absorbance before the UV exposure. The decay constants and corresponding lifetimes were calculated as described in Fig. S1. The linear regression trend line was constrained to have a $y$ intercept of zero. Error bars were calculated from the standard error of the slope of the linear trend line, the first-order rate constant. It should be noted that lifetimes of $\mathrm{BrC}$ absorption and chromophores given in this paper are lower-limit estimates since there are uncertainties due to scattering by the Teflon substrate (Presser et al., 2014).

\section{Results and discussion}

\subsection{BrC chromophores}

Table 1 summarizes $\mathrm{BrC}$ chromophores observed in two or more fires or fuel types. The table numbers BrC chromophores by their ascending retention time on the HPLC column, i.e., with smaller, more polar compounds appearing first. Each entry includes the absorption spectrum recorded by the PDA detector, the chemical formula(s) corresponding to the detected characteristic masses at that retention time, and a potential structure based on a spectra acquired from standards or observations in previous studies. All PDA chromatograms were integrated over $300-700 \mathrm{~nm}$ and normalized to the maximum integrated absorbance. Chromophores in Table 1 are binned with respect to their normalized PDA absorbance as $\mathrm{M}$ - major (75\%-100\%); I - intermediate (25\%-75\%); or W - weak (5\%-25\%). Abundance and absorption cross sections of $\mathrm{BrC}$ chromophores both factor into their assigned absorbance bin, as absorbance was not mass normalized with standards. It is possible that the chromophores labeled as " $\mathrm{M}$ " are present in small concentrations but have a large absorption coefficient. Compounds making up less than $5 \%$ of the normalized absorbance are not included in the table.

Lignin pyrolysis products make up one group of $\mathrm{BrC}$ chromophores observed. Lignin is a large, heterogeneous biopolymer that is a significant component of wood, along

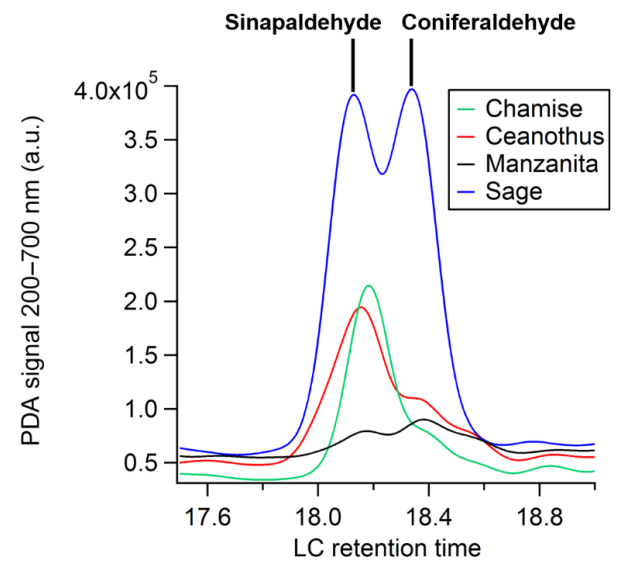

Figure 2. The lignin pyrolysis products sinapaldehyde $\left(\mathrm{C}_{11} \mathrm{H}_{12} \mathrm{O}_{4}\right)$ and coniferaldehyde $\left(\mathrm{C}_{10} \mathrm{H}_{10} \mathrm{O}_{3}\right)$ elute at slightly different retention times, roughly 18.1 and $18.4 \mathrm{~min}$, respectively.

with cellulose and hemicellulose. Lignin monomer units vary depending on the class of the plant but generally possess phenolic moieties that are largely preserved during pyrolysis (Simoneit et al., 1993). Sinapaldehyde (8) and coniferaldehyde (9) are known lignin pyrolysis products derived from the corresponding lignin monomer units, sinapyl and coniferyl alcohol, respectively. However, they are detected in varying abundance depending on the lignin monomer units of the plant class. Sinapaldehyde and coniferaldehyde are separated by the column but elute only $0.3 \mathrm{~min}$ apart, as shown in Fig. 2. Sinapaldehyde is a major BrC chromophore for nearly all angiosperm or flowering fuel types, including ceanothus, chamise, and sagebrush, while coniferaldehyde is a major $\mathrm{BrC}$ chromophore largely among conifers or soft wood species such as subalpine fir duff, longleaf pine, juniper, and ponderosa pine litter. Coniferaldehyde has one fewer methoxy ring substituent compared to sinapaldehyde, and its PDA intensity is generally anticorrelated to that of sinapaldehyde. In other words, for fuel types with low sinapaldehyde absorbance, we observe coniferaldehyde as a major $\mathrm{BrC}$ chromophore and vice versa. This is consistent with the composition of lignin monomers for angiosperms and gymnosperms (Sarkanen and Ludwig, 1971; Simoneit et al., 1993).

Other $\mathrm{BrC}$ chromophores cannot be classified as lignin pyrolysis products but are clearly lignin-derived. Vanillic acid (1) elutes at $10.07-10.29 \mathrm{~min}$ as the first, shared chromophore across multiple fuel types that is notable in terms of absorption. It is observed in three fires as a weak chromophore, including subalpine fir duff, ponderosa pine rotten log, and Engelmann spruce duff. All three fires are dominated by smoldering combustion and have the lowest modified combustion efficiencies (MCEs) of all fires (Table S1). This evidence suggests that vanillic acid is a product of smoldering combustion. Further, it also has the coniferyl moiety observed for softwoods. Salicylic acid (3) is an intermediate- 


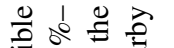

可记 。

पे

跣园

言 $\Sigma$

$\approx \ddot{\Xi} \otimes$

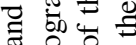

s.

灵

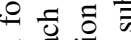

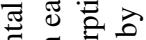

ए.

ब ह

항

त

\begin{tabular}{|c|c|c|c|c|}
\hline 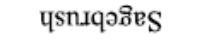 & & & & $B$ \\
\hline Iy se[ônod & & $B$ & $B$ & ↔ \\
\hline 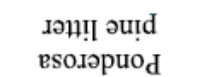 & & $\rightarrow$ & $B$ & $B$ \\
\hline 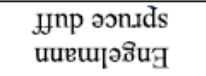 & $B$ & & & $B$ \\
\hline 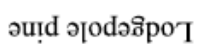 & & $B$ & $t$ & $\Sigma$ \\
\hline ę̣urzuew & & $\Sigma$ & $B$ & $\mapsto$ \\
\hline $\begin{array}{l}\text { ธిоI әu!d } \\
\text { psosəpuo }\end{array}$ & $B$ & & & \\
\hline $\operatorname{sədịun}_{f}$ & & $B$ & & $B$ \\
\hline 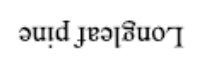 & & $\mapsto$ & 3 & $\mapsto$ \\
\hline
\end{tabular}

항

호 올 己

है ए

ํㅡㄹ 을

s

छ ष ठ

ธี ซิ

$=0 \frac{5}{5}$

क्ष

U

ส

흐응

음

금

उ

矛过

$\stackrel{\oplus}{=} \dot{0}$

ชิ

है

힝

जे है

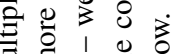

궁중

我 है

훙

등

>o $\bar{\sigma}$

o 워요

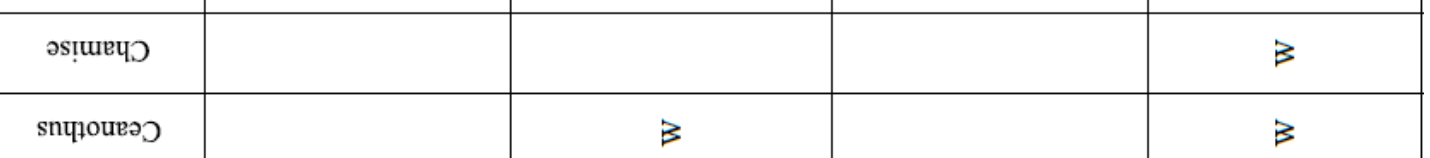

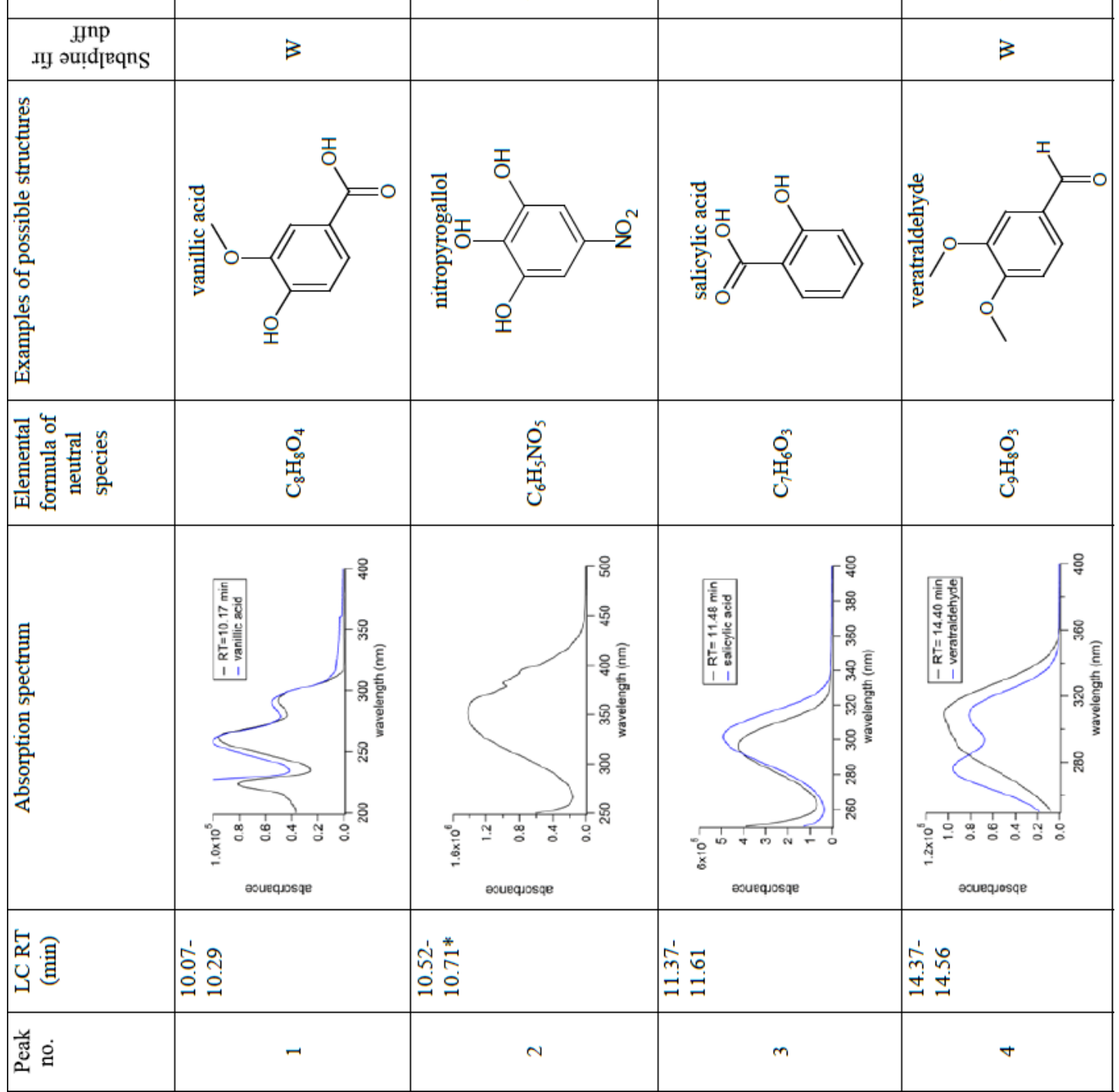




\begin{tabular}{|c|c|c|c|c|}
\hline$\infty$ & $v$ & $a$ & $u$ & : \\
\hline 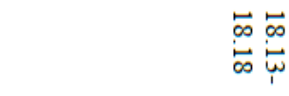 & $\begin{array}{l}\vec{N} \\
\text { 怘 }\end{array}$ & 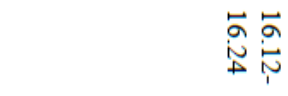 & 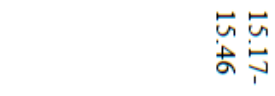 & 會员 \\
\hline (1) & absorance & absarbance & 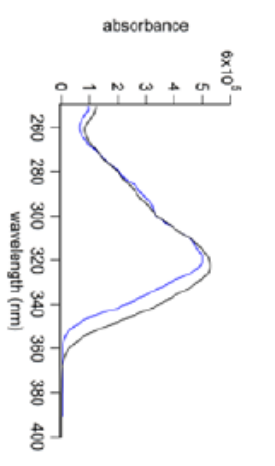 & 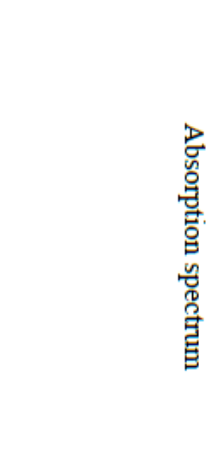 \\
\hline 害 & $\begin{array}{l}\text { 苟 } \\
\text { 苟 }\end{array}$ & $\begin{array}{l}\text { م् } \\
\text { 员 } \\
\text { ○ }\end{array}$ & 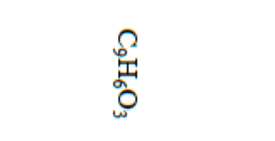 & 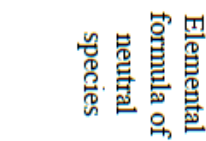 \\
\hline 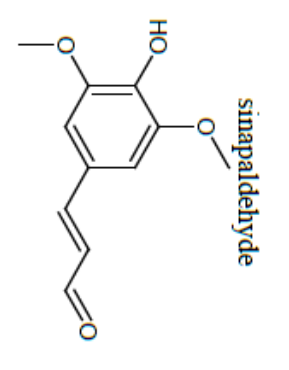 & 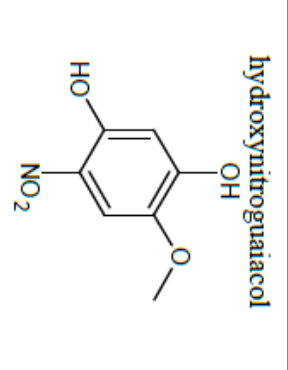 & $\underbrace{}_{\sim}$ & & 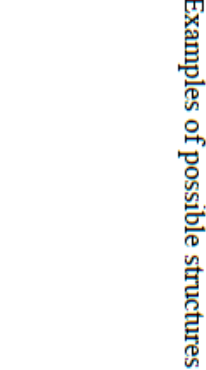 \\
\hline & $\varangle$ & & $\varangle$ & $\begin{array}{c}\text { Subalpine fir } \\
\text { duff }\end{array}$ \\
\hline 3 & & \& & \& & Ceanothus \\
\hline 3 & & 七 & & Chamise \\
\hline 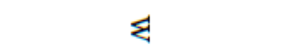 & ₹ & ¿ & « & Longleaf pine \\
\hline & 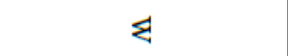 & & $\mapsto$ & Juniper \\
\hline 3 & 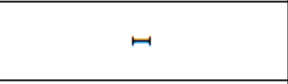 & & \& & $\begin{array}{c}\text { Ponderosa } \\
\text { pine log }\end{array}$ \\
\hline 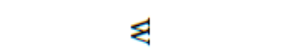 & 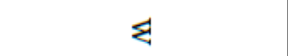 & & 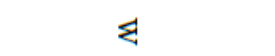 & Manzanita \\
\hline & \& & & ¿ & Lodgepole pine \\
\hline 3 & 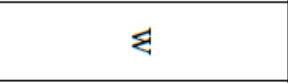 & & ะ & $\begin{array}{l}\text { Engelmann } \\
\text { spruce duff }\end{array}$ \\
\hline & 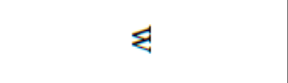 & $\varangle$ & & $\begin{array}{l}\text { Ponderosa } \\
\text { pine litter }\end{array}$ \\
\hline & ঊ & & ঊ & Douglas fir \\
\hline 3 & ধ & $\mapsto$ & ঊ & Sagebrush \\
\hline
\end{tabular}




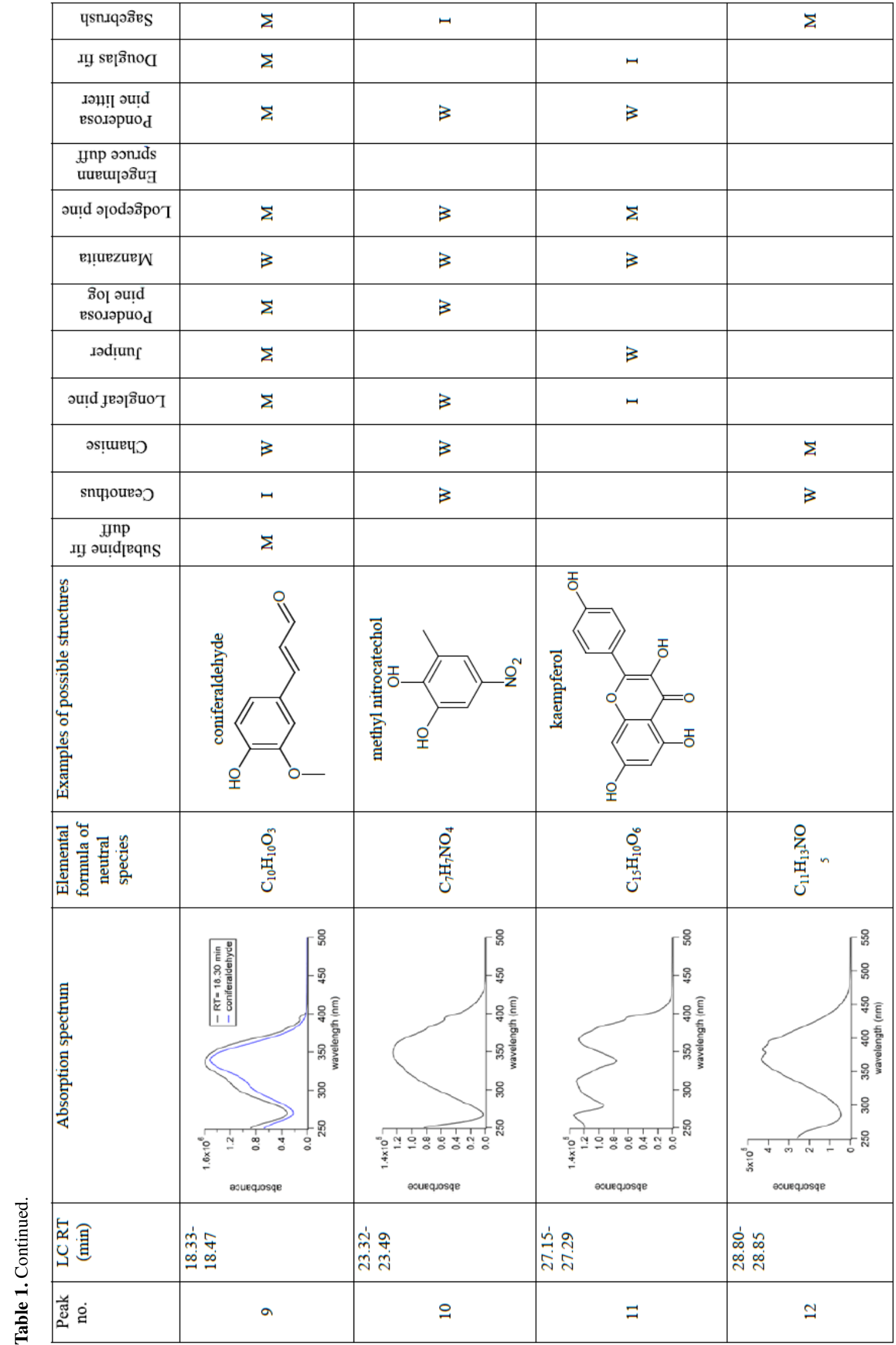




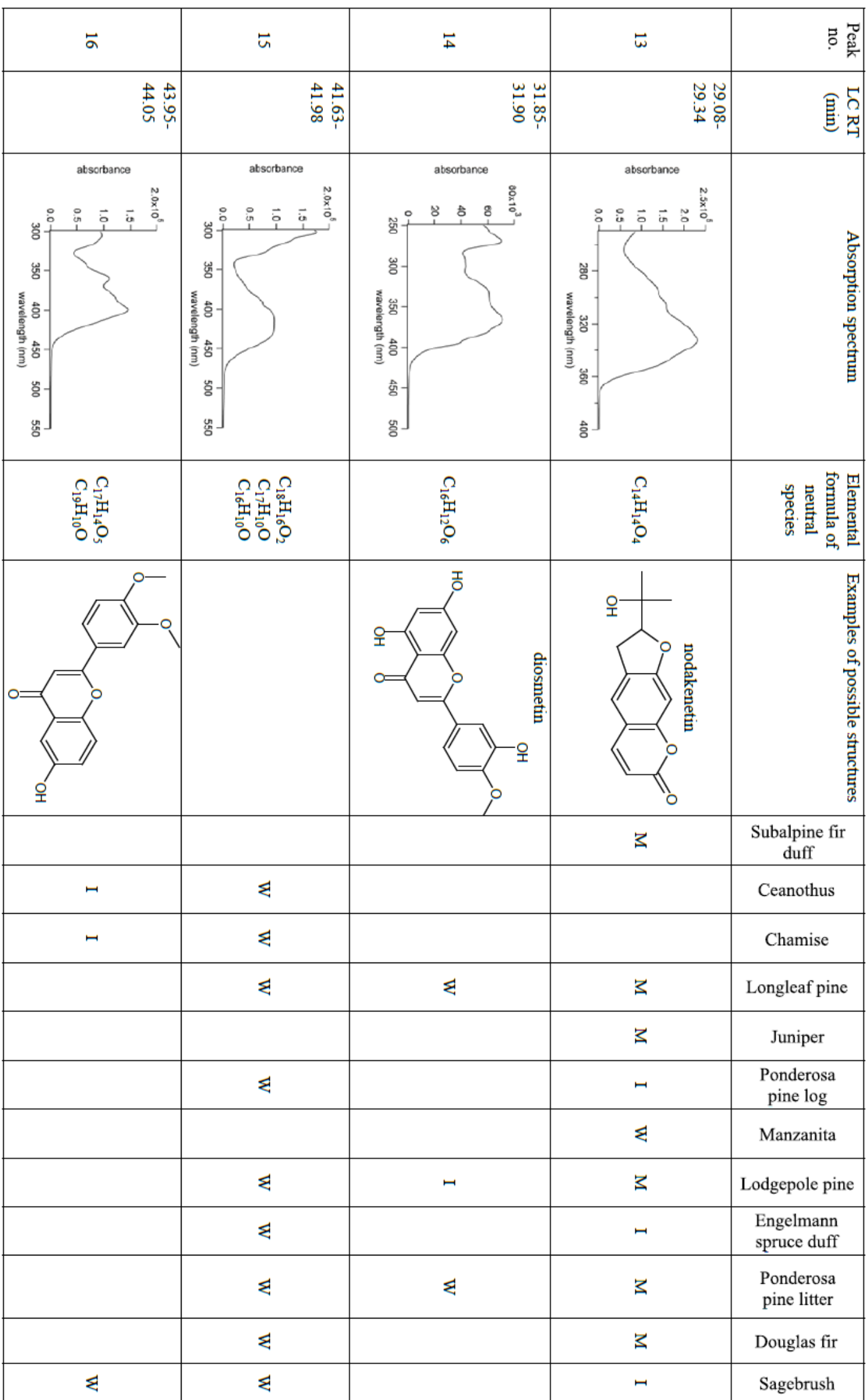




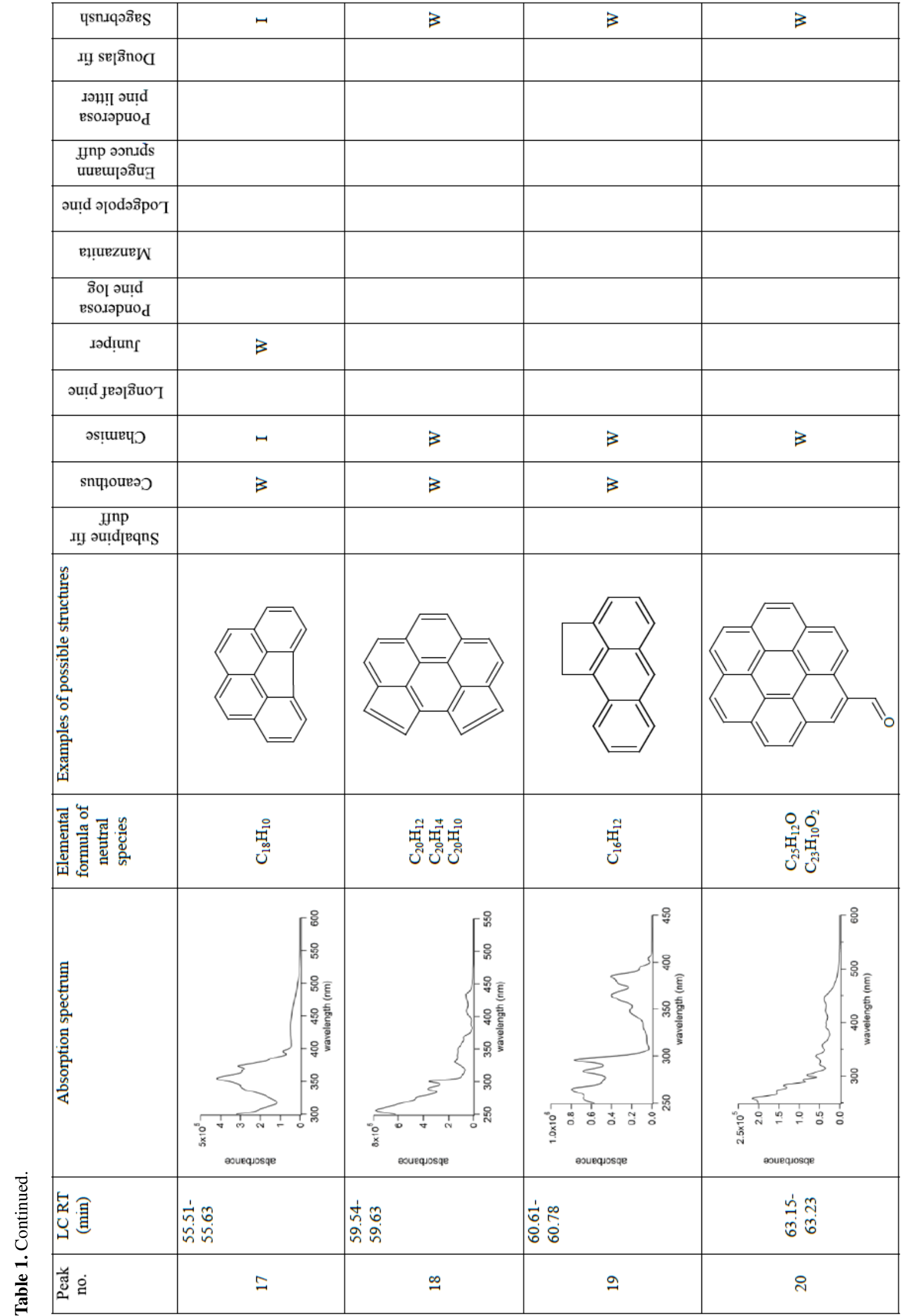




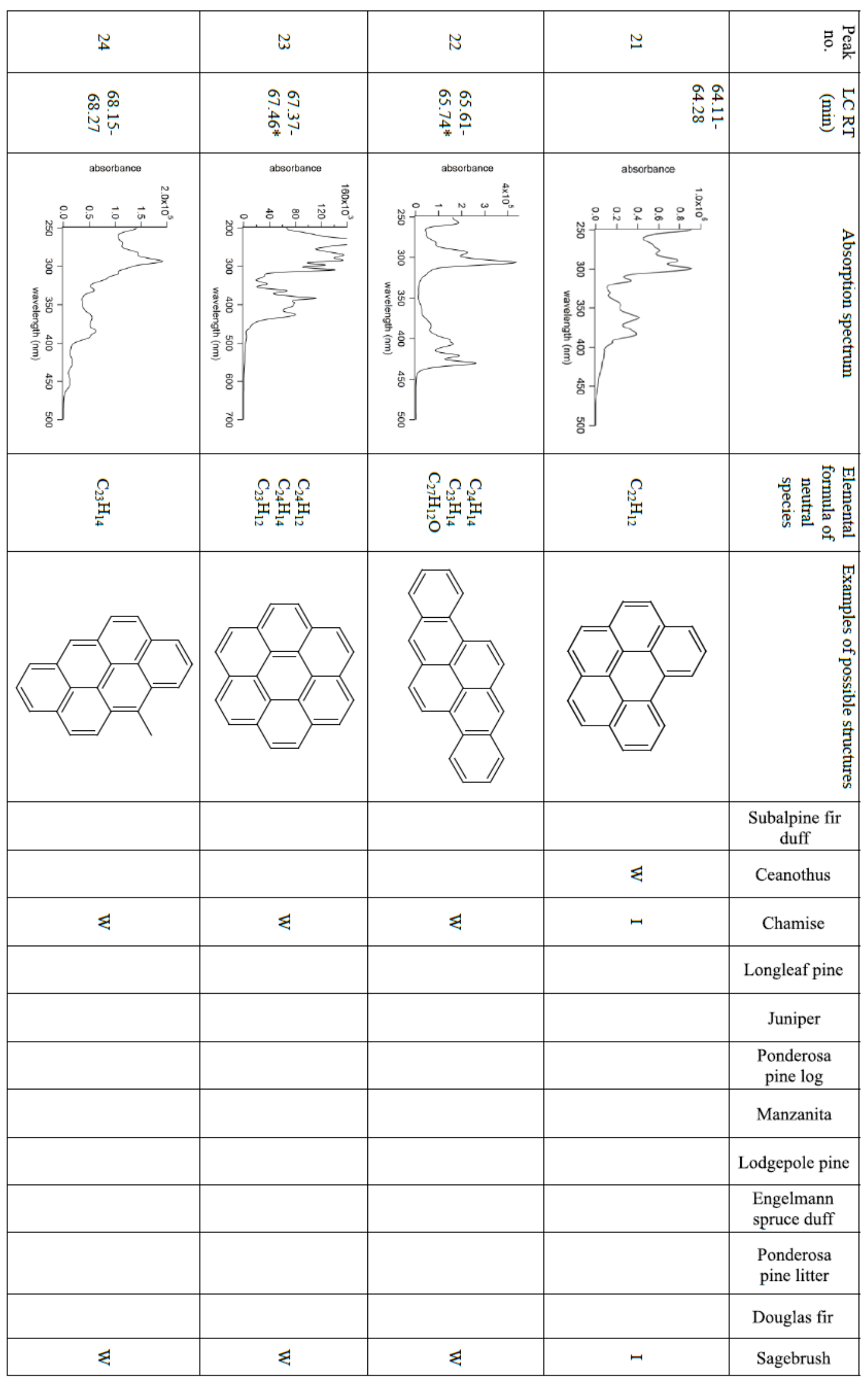




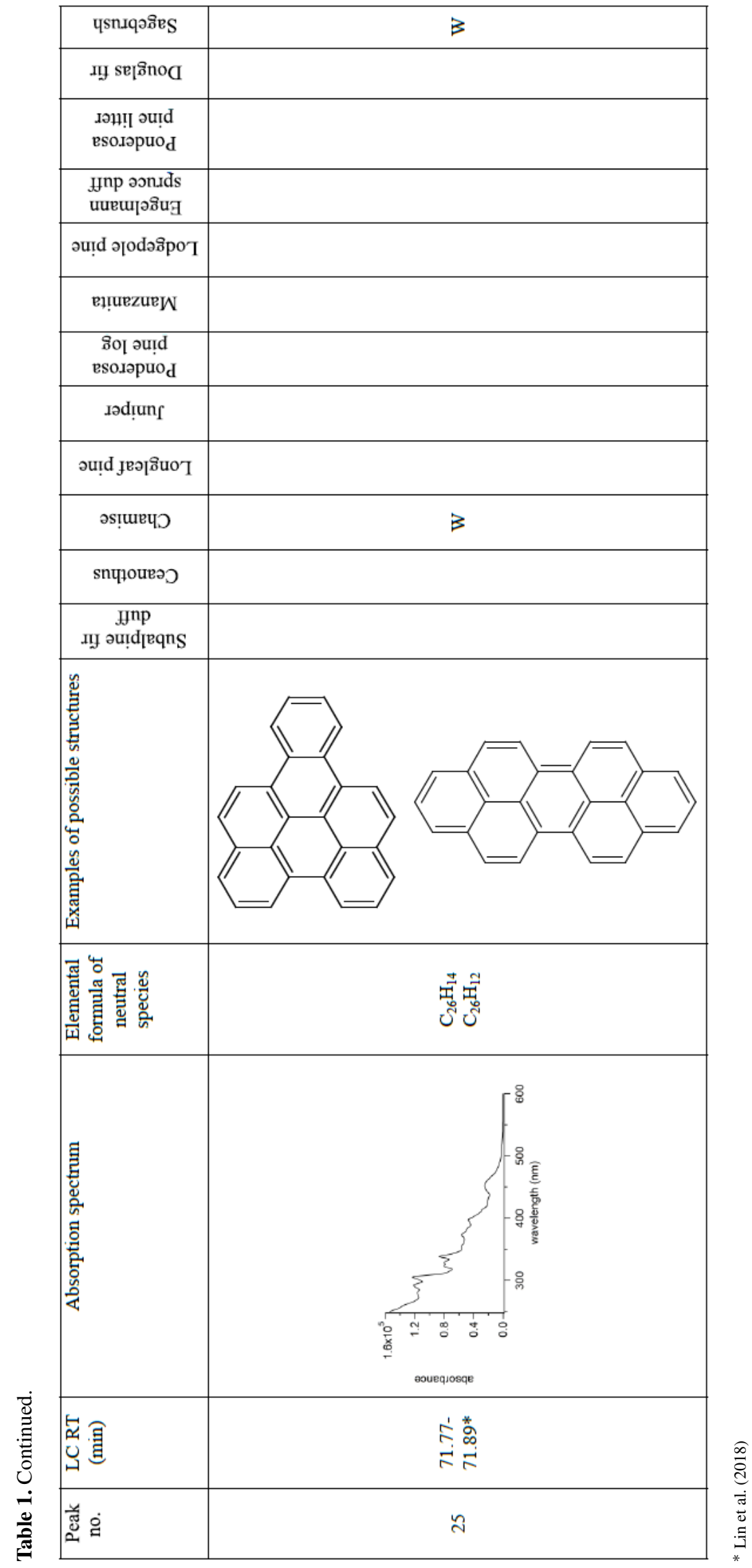


absorbing $\mathrm{BrC}$ chromophore produced during lodgepole pine burning, and weakly absorbing among other softwoods and duffs. Veratraldehyde (4) is another lignin-derived BrC chromophore, which appears in nearly all BBOA samples of this study, regardless of whether they are gymnosperm or angiosperm fuels.

There are other $\mathrm{BrC}$ chromophores with $\mathrm{C}_{x} \mathrm{H}_{y} \mathrm{O}_{z}$ composition that can be explained as distillation products, or the volatilization of molecules originating in plants as secondary metabolites (Agati et al., 2012; Iranshahi et al., 2009). Found in plants, coumarins such as umbelliferone (5) and nodakenetin (13) have been researched because of their positive pharmacological properties (Venugopala et al., 2013). The absorption spectrum for nodakenetin has not been reported; however, the molecule has previously been detected in plant tissues (Lee et al., 2003; Wang et al., 2014) and is a major or intermediate $\mathrm{BrC}$ chromophore in smoke from all fuel types except chamise and ceanothus. Another type of distillation product is flavonoids, which give leaves, flowers, and fruits their color, protecting the plant from solar UV radiation, and are antioxidants, guarding the plant from reactive oxygen species (Agati et al., 2012). Flavones and flavonols have the backbone structure of 2-phenyl-1benzopyran-4-one, and flavonols additionally require a hydroxy substituent on the only available carbon of the pyranone ring. BrC chromophores 11, 14, and 16 could have flavonoid structures based on their chemical formulas. Interestingly, tentatively assigned kaempferol (11) and diosmetin (14) are observed in only conifer species, such as lodgepole pine and longleaf pine. On the other hand, 7-hydroxy3',4'-dimethoxyflavone (16) is only observed in angiosperm BBOA: ceanothus, chamise, and sagebrush. The former two plants appear to be related as they have the order Rosales in common, which could explain the same flavone detected in both. Coumarins and flavonoids were distillation products observed across fuel types, although the observation of specific $\mathrm{BrC}$ chromophores depends on the plant class, i.e., angiosperm or gymnosperm.

Nitroaromatics are a strongly absorbing class of $\mathrm{BrC}$ chromophores that are formed from the reaction of aromatics with $\mathrm{NO}_{x}$ in plumes (Harrison et al., 2005). This class of compounds is represented in Table 1 with nitropyrogallol (2), nitrocatechol (6), hydroxynitroguaiacol (7), and methyl nitrocatechol (10). Xie et al. (2019) suggest that chromophore (12) with the chemical formula $\mathrm{C}_{11} \mathrm{H}_{13} \mathrm{NO}_{5}$ is not a nitroaromatic compound but rather a compound containing a different nitrogen-containing functional group, such as a nitrile group. We did not observe this group of chromophores for fires with low $\mathrm{NO}_{x}$ levels, such as duff, as qualitatively indicated by the peak NO level (Table S1). Nitrocatechol and methyl nitrocatechol are tracers for BBOA emissions formed from the photooxidation of phenol or $m$-cresol, toluene, and other aromatic compounds in the presence of $\mathrm{NO}_{x}$ (Iinuma et al., 2010, 2016; Lin et al., 2015a). These chromophores are most prominent in BBOA from chamise and sagebrush burns. Those two fires exhibited the highest NO mixing ratios in the entire study -3.79 ppmv $(82 \%$ of total $\mathrm{N}$ emissions) and 1.62 ppmv (57\% of total $\mathrm{N}$ emissions) peak NO values, respectively. Nitropyrogallol (2) has an additional hydroxy group and is likely formed in the same way as nitrocatechol and methyl nitrocatechol but is more oxidized. A compound with the same formula as nitropyrogallol (2) was observed during the photooxidation of nitrocatechol in the lab (Hems and Abbatt, 2018). This is an intermediate or major $\mathrm{BrC}$ chromophore detected in BBOA samples from longleaf pine, manzanita, and ponderosa pine litter fires. Hydroxynitroguaiacol (7) was observed in 10 of the 12 fires and is most prominent in ponderosa pine log BBOA despite this fire having the lowest $\mathrm{NO}$ levels. However, it may still form through photooxidation of guaiacol in the presence of $\mathrm{NO}_{x}$ (Hems and Abbatt, 2018). Nitrocatechol and methyl nitrocatechol are often used as biomass burning tracers in aged plumes (Al-Naiema and Stone, 2017; Iinuma et al., 2010; $\mathrm{Li}$ et al., 2016). However, in addition to these, we observed more oxidized versions of these nitroaromatic species with varying abundance depending on the $\mathrm{BrC}$ chromophore and test fire. This suggests that the BBOA markers nitrocatechol and methyl nitrocatechol become more functionalized on relatively short timescales (less than $2 \mathrm{~h}$ ) due to photooxidative aging.

Polycyclic aromatic hydrocarbons (PAHs) are known to be products of incomplete combustion, and they have the potential to be long-lived $\mathrm{BrC}$ chromophores despite their reactivity (Keyte et al., 2013). PAHs have been observed in pristine environments, and it has been suggested that this is due to phase separation of particles and slow diffusivity of PAHs to surfaces where they react with atmospheric oxidants (Fernández et al., 2002; Keyte et al., 2013; Macdonald et al., 2000; Sofowote et al., 2011; Zhou et al., 2012, 2019). In addition to its climatic effects, PAHs are mutagenic and carcinogenic as their metabolites, diol epoxides, bind to guanidine nucleobases in DNA, effectively leading to mutations (Finlayson-Pitts and Pitts, 2000; Moorthy et al., 2015; Wood et al., 1984; Xue and Warshawsky, 2005; Zhou et al., 2017). Various PAHs (17-25, Table 1) were observed in only ceanothus, chamise, and sagebrush BBOA. PAHs in Table 1 are detected from positive ion mode ESI, and although positive mode ESI is not optimal for observing PAHs, larger PAHs are still detectable by this method (Cha et al., 2018). The same PAHs were previously observed by Lin et al. (2018) for sagebrush using atmospheric pressure photoionization (APPI) coupled with HPLC-PDA-HRMS, which is more sensitive for the detection of nonpolar aromatic compounds. In general, individual PAH chromophores are binned as "weak" in Table 1 based on their contribution to optical absorption, but, for BBOA sampled from flaming sagebrush and chamise burns, they make up a significant fraction of the overall light absorption by $\mathrm{BrC}$.

Table 2 presents abundant $\mathrm{BrC}$ chromophores observed only in a single type of biomass fuel emissions. It should be 
Table 2. Chromophores appreciably found in only one fuel type, listed by their HPLC retention time, absorption spectra, assigned elemental formulas, and examples of possible structures. The absorbance by each chromophore is binned by integrated photodiode array absorbance normalized to the highest absorbance in each chromatogram: $\mathrm{M}$ - major (75\%-100\%); I - intermediate $(25 \%-75 \%)$; or W - weak $(5 \%-$ $25 \%)$.

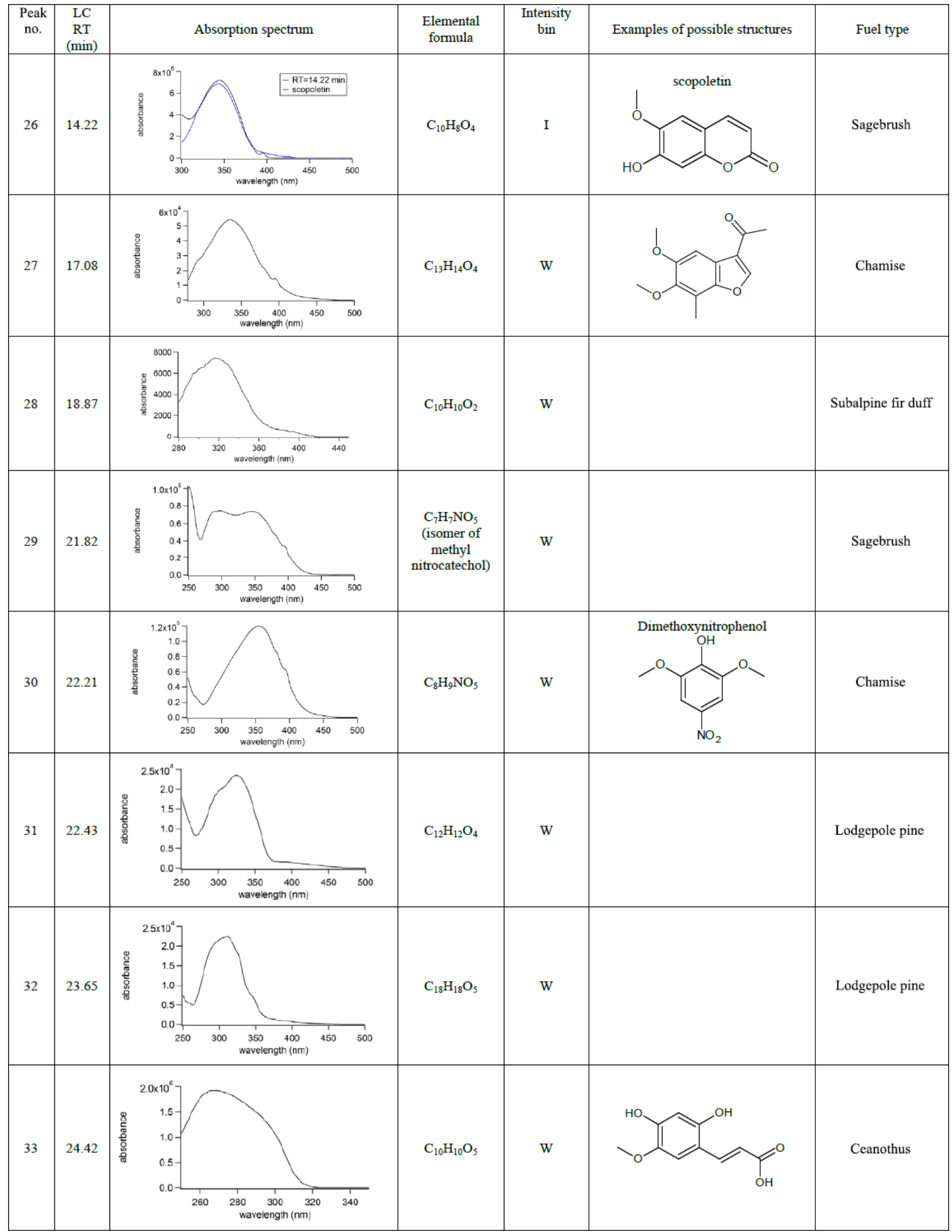


1120

L. T. Fleming et al.: Molecular composition and photochemical lifetimes of BBOA brown carbon

Table 2. Continued.

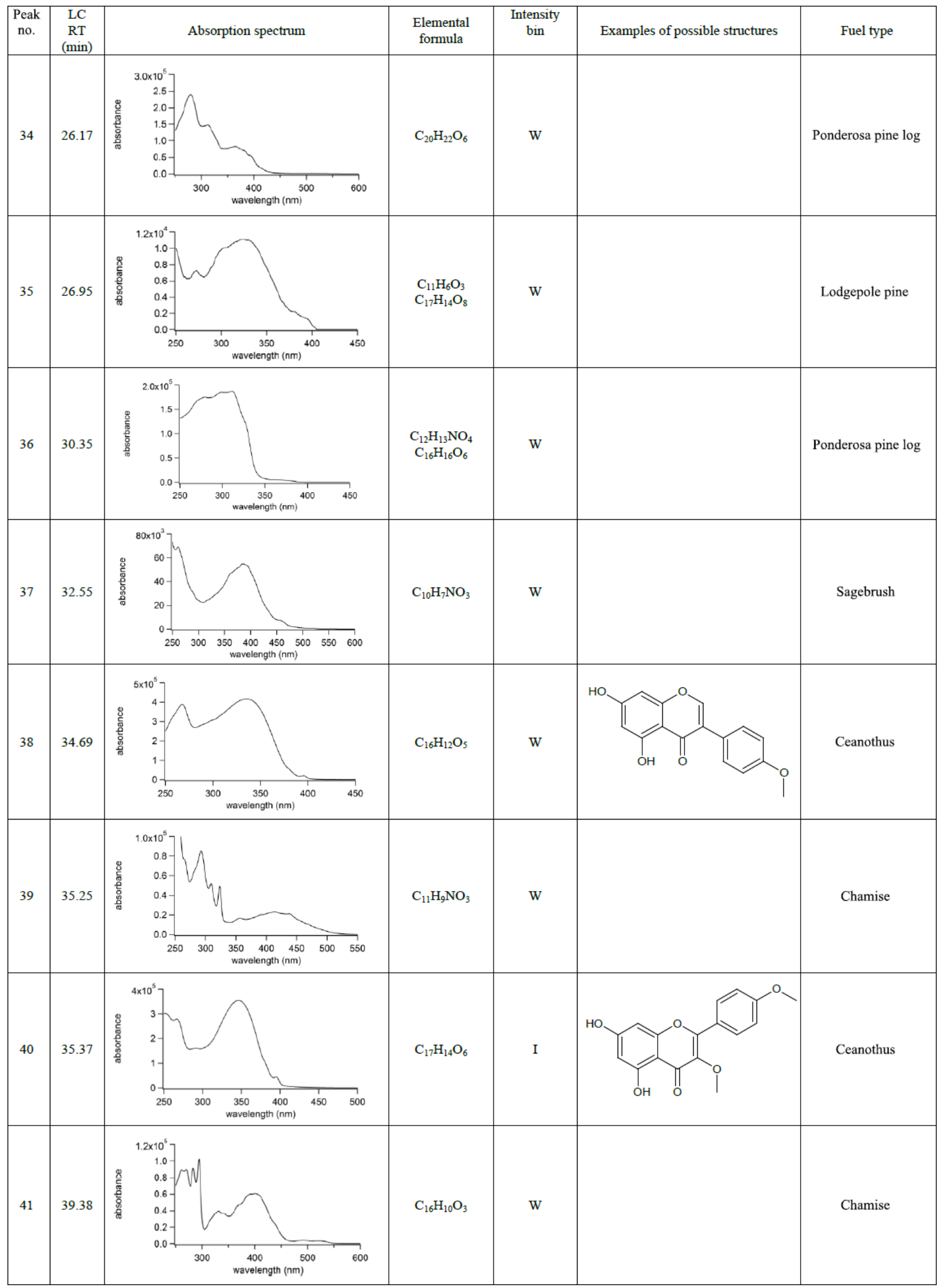

Atmos. Chem. Phys., 20, 1105-1129, 2020

www.atmos-chem-phys.net/20/1105/2020/ 
Table 2. Continued.

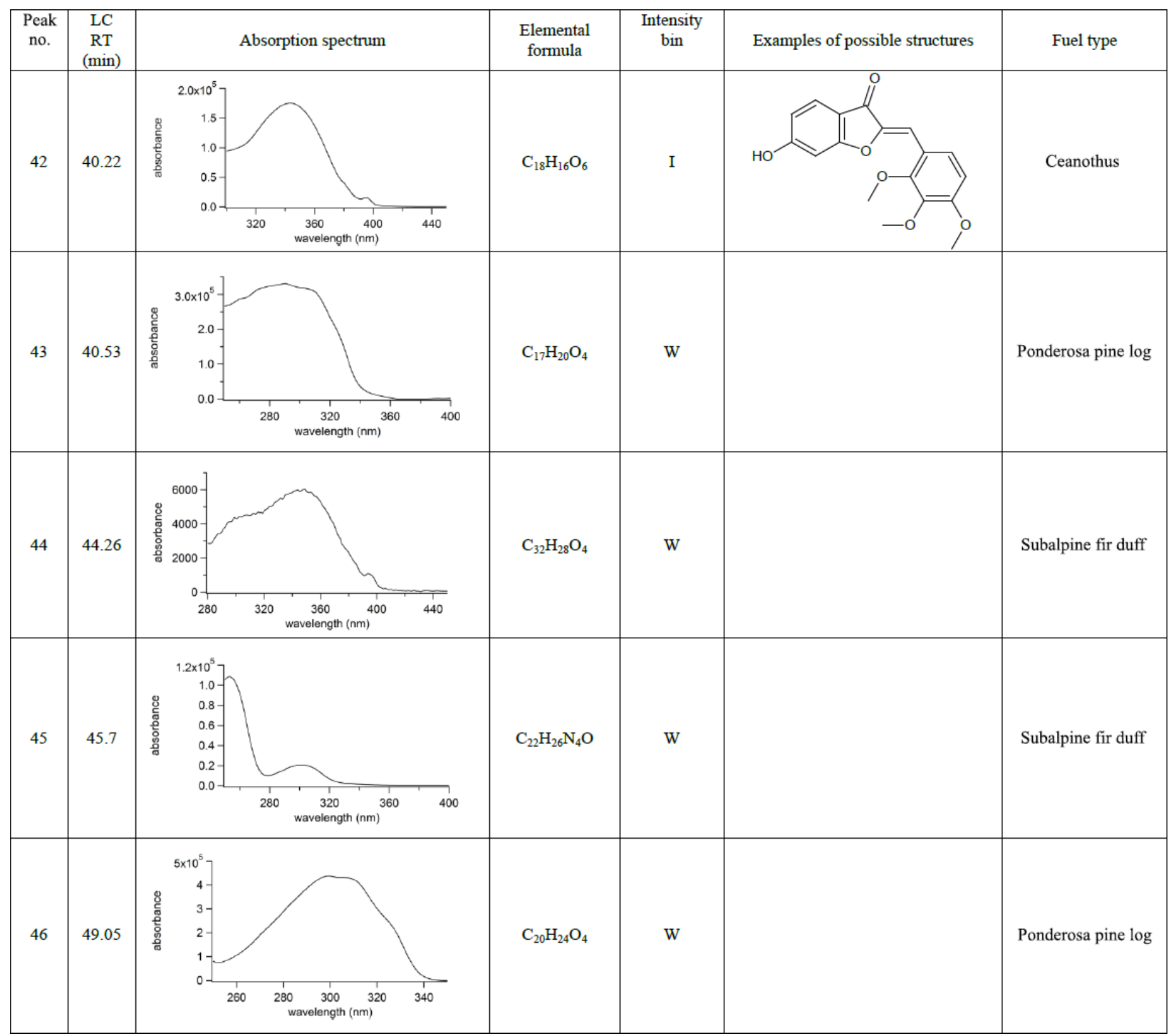

noted that compounds making up less than $5 \%$ of the normalized PDA absorbance (integrated from 300 to $700 \mathrm{~nm}$ ) are not included in the tables. Due to this constraint, chromophores in Table 2 may also be present in other fires but at very low PDA absorbance values. Despite BrC chromophores in Table 2 being observed significantly for only one fuel type, they belong to the same compound classes as the BrC chromophores in Table 1. For example, a coumarin known as scopoletin (26) was observed from sagebrush BBOA. Previously we discussed that these coumarins are possible distillation products, along with flavonoids, which we also observe as a product (40) from the ceanothus fire. These distillation products (26 and 40) are among the most strongly absorbing of the $\mathrm{BrC}$ chromophores, characterized as intermediate or "I" in Table 2.

\subsection{Aging by condensed-phase photochemistry}

Gymnosperm (lodgepole pine) and angiosperm (ceanothus) BBOA particle samples were selected for the initial condensed-phase photochemistry experiments. BBOA filter samples from a lodgepole pine burn were irradiated for $6 \mathrm{~h}$ by an LED centered around $300 \mathrm{~nm}$ (which corresponds to approximately $33 \mathrm{~h}$ of irradiation from $24 \mathrm{~h}$ average solar flux density; see Eq. 1). BBOA from the ceanothus burn were irradiated by the same LED for $16 \mathrm{~h}$ (equivalent to $88 \mathrm{~h}$ of $24 \mathrm{~h}$ averaged atmospheric sunlight). The burning of gymnosperm (lodgepole pine) and angiosperm (ceanothus) resulted in different distributions of $\mathrm{BrC}$ chromophore classes. However, the same compound classes, lignin-derived and flavonoid compounds, were photo-resistant in both samples. 


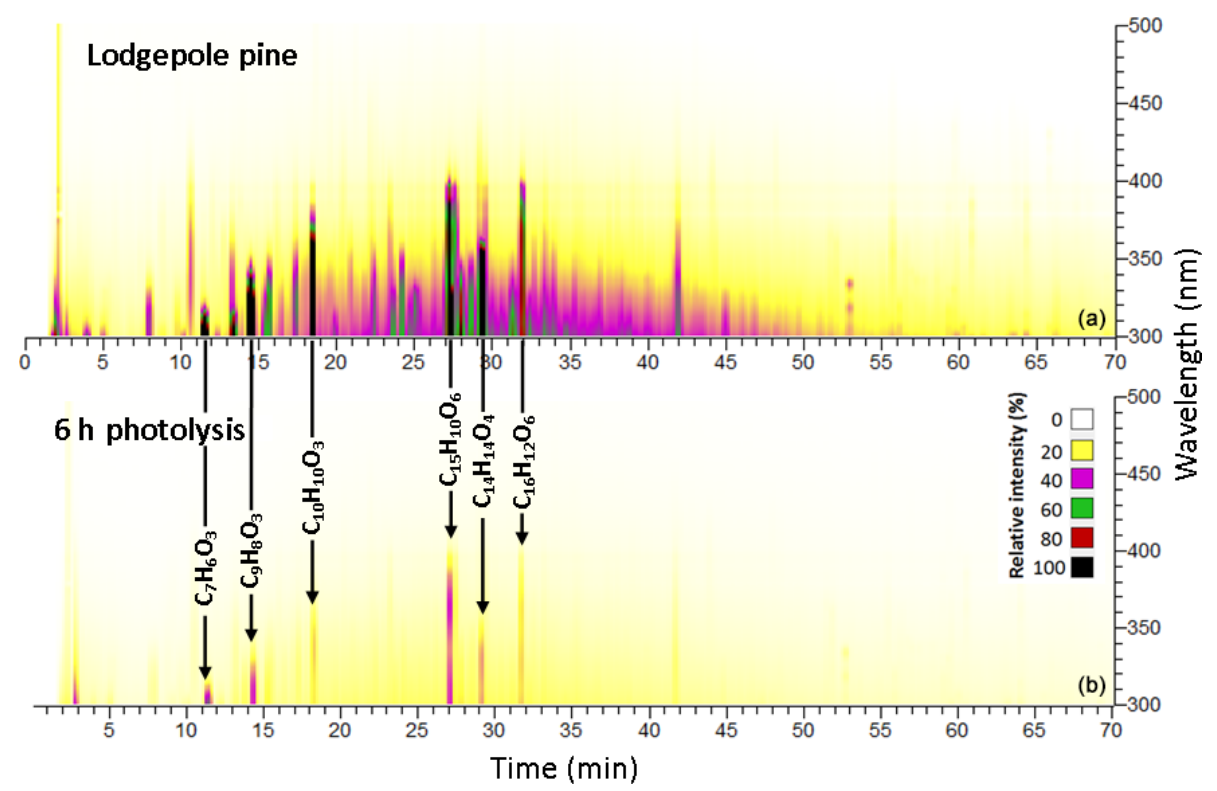

Figure 3. BrC chromophores present in the BBOA sample before (a) and after (b) $300 \mathrm{~nm}$ irradiation for a conifer fuel: lodgepole pine.

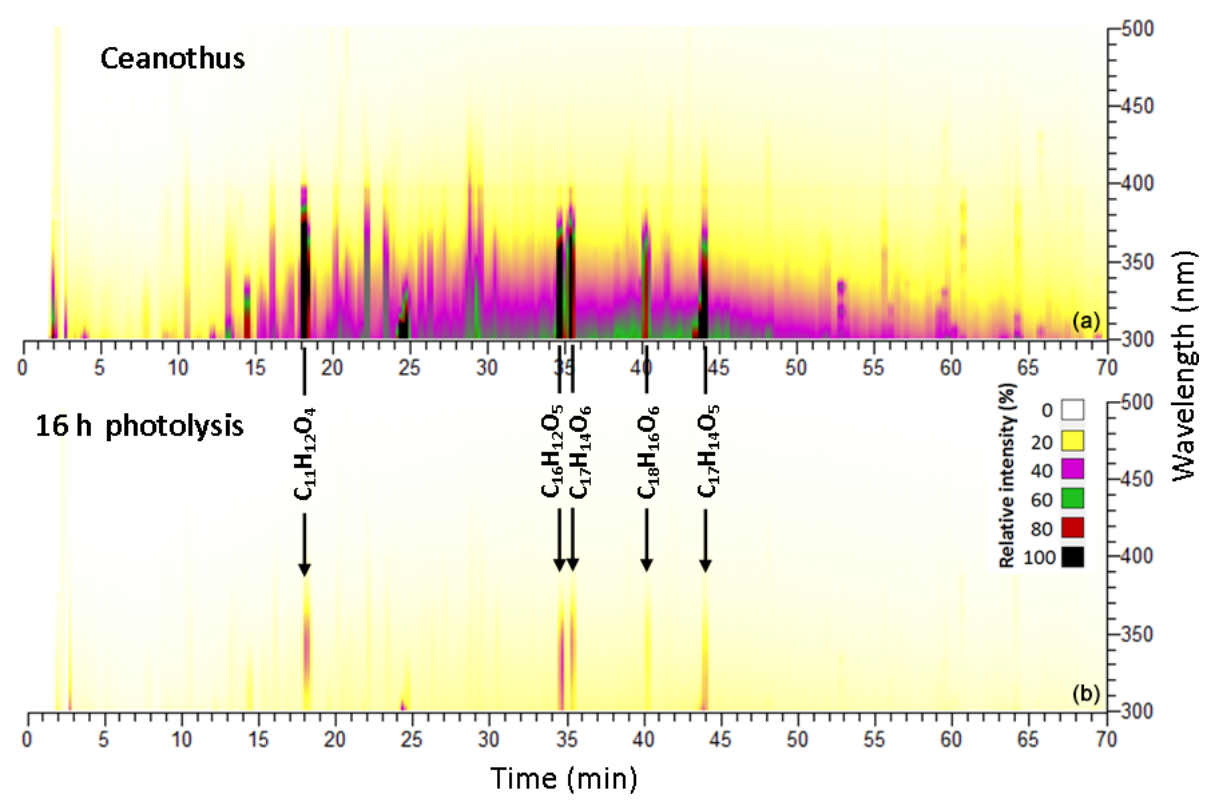

Figure 4. BrC chromophores present in the BBOA sample before (a) and after (b) $300 \mathrm{~nm}$ irradiation for an angiosperm fuel: ceanothus.

Most chromophores from the lodgepole pine burn sample experienced complete photobleaching during this exposure, but six of them remained observable, including coniferaldehyde $\left(\mathrm{C}_{10} \mathrm{H}_{10} \mathrm{O}_{3}, 80 \%\right.$ decrease $)$, salicylic acid $\left(\mathrm{C}_{7} \mathrm{H}_{6} \mathrm{O}_{3}\right.$, $70 \%$ decrease), veratraldehyde $\left(\mathrm{C}_{9} \mathrm{H}_{8} \mathrm{O}_{3}, 90 \%\right.$ decrease), flavonoids $\left(\mathrm{C}_{15} \mathrm{H}_{10} \mathrm{O}_{6}\right.$ and $\mathrm{C}_{16} \mathrm{H}_{12} \mathrm{O}_{6}$, both $70 \%$ decrease), and nodakenetin $\left(\mathrm{C}_{14} \mathrm{H}_{14} \mathrm{O}_{4}, 90 \%\right.$ decrease), as shown in Fig. 3. Figure 4 shows five chromophores from the ceanothus burn sample that remained observable under these conditions, including sinapaldehyde $\left(\mathrm{C}_{11} \mathrm{H}_{12} \mathrm{O}_{4}, 90 \%\right.$ decrease $)$, a lignin-derived chromophore $\left(\mathrm{C}_{18} \mathrm{H}_{16} \mathrm{O}_{6}, 80 \%\right.$ decrease), and flavonoids $\left(\mathrm{C}_{16} \mathrm{H}_{12} \mathrm{O}_{5}, \mathrm{C}_{17} \mathrm{H}_{14} \mathrm{O}_{6}\right.$, and $\mathrm{C}_{17} \mathrm{H}_{14} \mathrm{O}_{5}$, all $80 \%$ decrease), some of which were observed exclusively in this fire. These comparatively resilient species are aromatic, which helps them be more resistant to photodegradation.

Next, we estimate the lifetime of individual $\mathrm{BrC}$ chromophores in BBOA. For chamise, manzanita, and lodgepole pine fires we measured the integrated PDA intensity over $300-700 \mathrm{~nm}$ for chromatographically separated $\mathrm{BrC}$ chromophores in the starting samples and for up to three irra- 


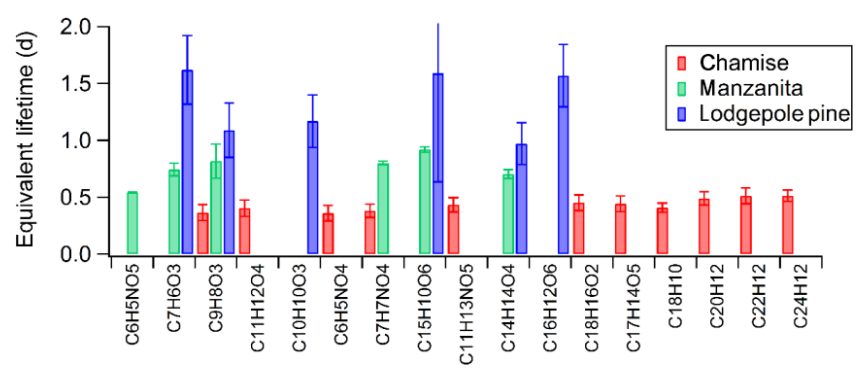

Figure 5. Approximate atmospheric lifetimes for select individual BrC chromophores due to UV irradiation in BBOA from chamise, manzanita, and lodgepole pine fires (the irradiation times are listed in Table S2). These lifetimes are shorter than those calculated for overall $\mathrm{BrC}$ absorption.

diation time points (listed in Table S2). The limited number of samples and destructive nature of the chemical analysis only made it possible to do measurements for very few time points. Integrated PDA intensities as a function of irradiation time were fit assuming that the decay was exponential in time. LED lifetimes were then converted to equivalent lifetimes in the atmosphere, calculated from the average spectral flux density over 20 June 2017 in Los Angeles. It should be noted that due to scattering of light by the Teflon filter substrate, which effectively increases the absorption efficiency of particles trapped on the filter, lifetimes in Fig. 5 are lower limits (Presser et al., 2014). Regardless of the chromophore identities, $\mathrm{BrC}$ chromophores from chamise burns have shorter predicted lifetimes $(0.4-0.5 \mathrm{~d})$ than those from manzanita burns $(0.5-0.9 \mathrm{~d})$, which in turn have shorter predicted equivalent atmospheric lifetimes due to sunlight exposure than $\mathrm{BrC}$ from lodgepole pine burns (1.0-1.6 d), as shown in Fig. 5. These lifetimes of $\mathrm{BrC}$ chromophores are consistent with atmospheric observations of a rapid evolution in a California wildfire, which showed that the $\mathrm{BrC}$ absorbance lifetime at $370 \mathrm{~nm}$ was $9-15 \mathrm{~h}$ (Forrister et al., 2015).

The same chromophores were found to decay at different rates depending on the fuel/fire type (Fig. 5). For example, very different equivalent atmospheric lifetimes due to UV irradiation were obtained across fuel types for veratraldehyde (no. 4 in Table $1, \mathrm{C}_{9} \mathrm{H}_{8} \mathrm{O}_{3}$ ), a $\mathrm{BrC}$ chromophore common to all three fires. One explanation is that there are multiple chromophores co-eluting at this retention time, and therefore the calculation is an average lifetime for multiple compounds. A more interesting explanation is that the surrounding matrix could affect the rate of condensed-phase photochemical transformations for individual chromophores by several possible mechanisms. First, different matrices could quench the electronic excitation in the chromophores to a different extent. Another possibility is that photodegradation of $\mathrm{BrC}$ chromophores could be not due to direct photolysis but rather occurring through condensed-phase photosensitized reactions (Malecha and Nizkorodov, 2017; Monge et al., 2012), in which case the rate of decomposition would depend on concentration of photosensitizers in the samples as well as viscosity of the material (Hinks et al., 2016; Kaur et al., 2019). Lastly, other absorbing species, such as black carbon, could be shielding $\mathrm{BrC}$ chromophores from irradiation, altering the amount of radiation absorbed by $\mathrm{BrC}$ chromophores. Given the different mechanisms, the potential contributions from each are difficult to distinguish in this study. The particle matrix is different for all three BBOA particle samples and could contribute to the very different equivalent atmospheric lifetimes of individual $\mathrm{BrC}$ chromophores observed in Fig. 5.

We also estimated the decay lifetime for the overall $\mathrm{BrC}$ absorption, integrated over 300-700 nm, from different fuel types. In these experiments, BBOA filters were irradiated with a filtered xenon arc lamp, which gave a spectral flux density more similar to the Sun, although more intense (Fig. 1). The advantage of taking transmission spectra directly through the filters is that it makes it possible to monitor photodegradation of $\mathrm{BrC}$ absorption at several irradiation times, which is not possible with the solution-phase spectrophotometry, which irreversibly destroys the filter sample by extraction. The filter transmission spectra indicated that the decay of absorbance was not actually exponential. After a certain irradiation time, the $\mathrm{BrC}$ absorbance no longer decreased, as observed for the samples from subalpine fir and longleaf pine burns. For example, in Fig. S2, after $21 \mathrm{~h}$ the recalcitrant or "baseline $\mathrm{BrC}$ " level has already been reached, as revealed by the next measurement at $33 \mathrm{~h}$. The absorbance decreased $70 \%$ before it reached the baseline $\mathrm{BrC}$ level for subalpine fir, and $60 \%$ for longleaf pine. For estimates of the $\mathrm{BrC}$ absorbance lifetimes, we used only the time before reaching the final light-absorbance state. Table 3 summarizes the resulting lifetimes for $\mathrm{BrC}$ from four fuel types, longleaf pine, juniper, lodgepole pine, and subalpine fir. Once again, it should be noted that $\mathrm{BrC}$ absorption lifetimes are lower limits, due to the enhanced efficiency of absorption by particles caused by scattering of UV radiation scattering by the Teflon filter substrate (Presser et al., 2014).

Once there was no further significant change in the transmission spectrum, the filter was extracted for the solutionphase UV-Vis measurement, in order to compare the spectra obtained from the filter and in the solution. The reduction in absorbance in the solution-phase spectra was comparable to that observed in the filter transmission spectra (Fig. S2). However, there were differences in the shape of the spectra - there was no measurable absorbance above $550 \mathrm{~nm}$ in the extracted samples, but filter samples absorbed even at these long wavelengths (Fig. S2). It is likely that the extraction from the filter was not complete, and some of the absorbers remained on the filter after the extraction. The latter is another advantage of doing these experiments with filter samples as opposed to their solvent extracts.

BBOA from subalpine fir (litter and other components) had the shortest equivalent absorption lifetime at $10 \mathrm{~d}$, and 
Table 3. Lifetimes for the loss of the measured integrated absorbance from 300 to $700 \mathrm{~nm}$. The results are expressed in equivalent days of solar exposure to either time-averaged solar flux in Los Angeles (middle column) or peak solar flux at $\mathrm{SZA}=0^{\circ}$ (right column). The lifetimes were calculated from the transmission spectra measured for particles on PTFE filters. The irradiation was done in the condensed phase on the filter for all samples.

\begin{tabular}{lrr}
\hline Fuel type & $\begin{array}{r}\text { BrC absorption } \\
\text { lifetime } \\
\text { averaged LA } \\
\text { (equivalent days) }\end{array}$ & $\begin{array}{r}\text { BrC absorption } \\
\text { lifetime } \\
\text { (equivalent days) }\end{array}$ \\
\hline Longleaf pine & $25 \pm 0$ & $8.5 \pm 0$ \\
Juniper & $41 \pm 4$ & $14 \pm 1$ \\
Ponderosa pine litter & $17 \pm 1$ & $6.0 \pm 0$ \\
Subalpine fir & $10 \pm 2$ & $3.4 \pm 1$ \\
\hline
\end{tabular}

ponderosa pine (litter and canopy) had the next shortest equivalent absorption lifetime at $17 \mathrm{~d}$. Different ecosystem biomass components were burned in the longleaf pine fire, such as duff, litter, and canopy, and had the next longest absorption lifetime of $25 \mathrm{~d}$. The longest living $\mathrm{BrC}$ absorbance, at $41 \mathrm{~d}$, was observed for the sample from juniper (canopy only) burn. Fuel components appear to affect BrC absorption lifetimes, as it does seem that non-canopy fuel components, such as litter and duff, lower the $\mathrm{BrC}$ absorption lifetimes. However, it is difficult to correlate the $\mathrm{BrC}$ absorption lifetimes with quantitative measures such as NO levels or MCE (Table S1). Table S1 shows that the peak NO level was lower for longleaf pine ( $0.67 \mathrm{ppmv})$ compared to juniper (1.72 ppmv) and ponderosa pine (1.61 ppmv), suggesting less flaming combustion may have occurred for the longleaf pine fire (although this is not reflected in the MCE trends). Regardless, the data suggest that $\mathrm{BrC}$ absorption can be longlived from direct photodegradation.

In general, the lifetimes for the loss of the absorbance integrated over 300-700 nm (Table 3) are much longer than those of individual chromophores (Fig. 5). There are two likely reasons for that. First, the photochemical transformation of individual chromophores creates product(s) that may also absorb in the same wavelength range. The integrated $\mathrm{BrC}$ absorption (300-700 nm) may significantly decrease only after the compounds go through several successive stages of photodegradation, finally resulting in products that no longer absorb above $300 \mathrm{~nm}$. The results of both UV irradiation experiments is consistent with work by $\mathrm{Di}$ Lorenzo et al. (2017) and Wong et al. (2017), which show that during aging, high-molecular-weight $\mathrm{BrC}$ chromophores are formed after lower-molecular-weight chromophores are photo-degraded. The high-molecular-weight fraction of $\mathrm{BrC}$ chromophores persists even at long aging times and are referred to as the recalcitrant fraction. This theory is one explanation for the short lifetimes of low-molecular-weight $\mathrm{BrC}$ compounds, while observing longer overall $\mathrm{BrC}$ absorption lifetimes. Second, Eq. (1), which we use to estimate lifetimes, does not take into account photochemical quantum yields, which tend to increase greatly at shorter wavelengths. The LED, which was used in measurements of lifetimes of individual chromophores, has a higher density of higherenergy photons compared to the Xe lamp (Fig. 1), which could accelerate the observed photodegradation rate.

The lifetimes for BrC photobleaching due to UV irradiation (10 to $41 \mathrm{~d}$ ) are longer than what other studies have observed or approximated for other aging mechanisms. Lin et al. (2016) found that peat and ponderosa pine BBOA had similar half-lives of around $16 \mathrm{~h}$ based on absorption coefficients at $300 \mathrm{~nm}$. However, in Lin et al. (2016), BBOA was extracted and irradiated in solution where photodegradation could occur more rapidly due to molecular diffusion (Lignell et al., 2014). Forrister et al. (2015) collected filter samples in the plumes of wildfires with different transport times during the SEAC4RS campaign and found that the $\mathrm{BrC}$ absorbance lifetime at $370 \mathrm{~nm}$ was $9-15 \mathrm{~h}$. Similarly, Selimovic et al. (2019) found a significant decrease in the absorption Angstrom exponent after $10 \mathrm{~h}$ of daytime aging during a wildfire event in the northwestern US. Sumlin et al. (2017) aged smoldering peat BBOA in an OFR and reported a decrease of $\sim 40 \%-50 \%$ in the aerosol mass absorption coefficients at 375 and $405 \mathrm{~nm}$ after 4.5 equivalent aging days. They attributed this decrease to fragmentation of $\mathrm{BrC}$ chromophores due to photooxidation (oxidation by gaseous $\mathrm{OH}$ ). Based on the comparison of these observations, photooxidation could be a more important aging mechanism affecting $\mathrm{BrC}$ absorption lifetimes than the UV-induced photochemical processes inside the particles.

\section{Conclusions and implications}

Samples of BBOA particles from laboratory burns of 12 forest fire fuels collected around the United States were analyzed for BrC chromophores. Biomass fuels spanned plant types (gymnosperm versus angiosperm) and ecosystem components (duff, litter, canopy, etc.). BrC chromophores were grouped among classes, including lignin pyrolysis products, lignin-derived products, distillation products (coumarins and flavonoids), nitroaromatics, and PAHs. While most $\mathrm{BrC}$ chromophore classes were observed in all burns, regardless of fuel type, there were specific $\mathrm{BrC}$ chromophores that were divided across angiosperm (flowering) and gymnosperm (conifer) lines. For example, sinapaldehyde was mainly observed in BBOA when angiosperm fuels were burned, and coniferaldehyde was mainly observed when gymnosperm fuels were burned. Additionally, there were flavonoids specific to conifers, tentatively kaempferol and diosmetin (Table 1, chromophores 11 and 14), and unique to angiosperms such as chromophore 16. PAHs are largely angiosperm $\mathrm{BrC}$ chromophores, showing up mainly for sagebrush, chamise, and ceanothus fuels. There are some $\mathrm{BrC}$ chromophores that are 
only appreciably observed in a single fuel type or burn; many of these are likely distillation or lignin-derived products. The most absorbing of these $\mathrm{BrC}$ chromophores are components of the angiosperm BBOA (Table 2).

UV irradiation of BBOA from different fuels directly on filters removes some $\mathrm{BrC}$ chromophores but some appear to be photo-stable, specifically, lignin-derived compounds (including lignin-pyrolysis products) and flavonoids. Interestingly, individual $\mathrm{BrC}$ chromophore lifetimes varied based on the fuel burned and perhaps the underlying combustion conditions, rather than just the structure of the chromophore. Part of the reason is that co-elution of chromophores with different stabilities complicates measurements of individual chromophore lifetimes. In addition, indirect photochemical mechanisms, such as photosensitized reactions, energy loss to neighboring molecules, and shielding of light by other absorbing molecules could change depending on the specific BBOA material. The BrC chromophores of chaparral fuels had shorter equivalent photochemical lifetimes compared to BBOA generated from the canopies of conifer fuel types. On the whole, these results suggest that some of the primary $\mathrm{BrC}$ chromophores may be destroyed by UV irradiation after several hours.

Despite the rapid change in the absorbance of individual chromophores, the overall integrated $\mathrm{BrC}$ absorbance from 300 to $700 \mathrm{~nm}$ decayed with a much longer lifetime of 10 to $41 \mathrm{~d}$. These observations contrast with individual chromophores in particles that decayed on the timescale of 0.4 to $1.6 \mathrm{~d}$. Taken together, the two types of UV irradiation experiments suggest that the absorption by the complete pool of $\mathrm{BrC}$ compounds persists during irradiation longer than the individual $\mathrm{BrC}$ chromophores detected. Our findings also show that ecosystem components, and the combustion conditions they create, could influence the apparent $\mathrm{BrC}$ absorption lifetimes. $\mathrm{BrC}$ from the subalpine fir mix burned with more smoldering combustion and had the shortest equivalent lifetime of $10 \mathrm{~d}$, while BBOA from the juniper and lodgepole canopy fuels had longer BrC absorption lifetimes of 25-41 d. The canopy fuels contributed to more flaming combustion. These fairly long $\mathrm{BrC}$ absorption lifetimes suggest that the that optical properties of $\mathrm{BrC}$ particles change slowly under UV-irradiated conditions and that other chemical aging mechanisms such as $\mathrm{OH}$ oxidation may be more important under atmospheric conditions. Based on these results, climate modelers should first focus on chemical aging mechanisms other than condensed-phase photochemistry, such as heterogeneous oxidation by $\mathrm{OH}$.

Data availability. All data used in this study are listed within the paper.

Supplement. The supplement related to this article is available online at: https://doi.org/10.5194/acp-20-1105-2020-supplement.
Author contributions. LTF, PL and AL collected and analyzed particulate matter samples. JMR, VS and RY analyzed gaseous composition. JL, AL and SAN assisted with interpretation of mass spectrometry data. LTF did the photochemistry experiments and wrote the paper. All co-authors provided edits and critical feedback for the paper.

Competing interests. The authors declare that they have no conflict of interest.

Acknowledgements. The chemical analysis portion of this work by were supported by NOAA-CPO grant no. NA16OAR4310102 (Lauren T. Fleming and Sergey A. Nizkorodov) and NOAA-CPO grant no. NA16OAR4310101 (Peng Lin, Julia Laskin and Alexander Laskin). Vanessa Selimovic and Robert Yokelson were supported by NOAA-CPO grant no. NA16OAR4310100. The photochemistry portion of this work was supported by NSF grant no. AGS-1853639. We thank the USFS Missoula Fire Sciences Laboratory for their help in conducting these experiments. This work was also supported by NOAA's Climate Research and Health of the Atmosphere Initiative. The HRMS measurements were performed at the W.R. Wiley Environmental Molecular Sciences Laboratory (EMSL) - a national scientific user facility located at PNNL - and sponsored by the Office of Biological and Environmental Research of the U.S. DOE. PNNL is operated for the U.S. DOE by the Battelle Memorial Institute under contract no. DE-AC06-76RL0 1830.

Financial support. This research has been supported by the National Oceanic and Atmospheric Administration, Climate Program Office (grant nos. NA16OAR4310100, NA16OAR4310101, and NA16OAR4310102) and the National Science Foundation (grant no. AGS-1853639).

Review statement. This paper was edited by Ryan Sullivan and reviewed by three anonymous referees.

\section{References}

Agati, G., Azzarello, E., Pollastri, S., and Tattini, M.: Flavonoids as antioxidants in plants: Location and functional significance, Plant Sci., 196, 67-76, https://doi.org/10.1016/j.plantsci.2012.07.014, 2012.

Al-Naiema, I. M. and Stone, E. A.: Evaluation of anthropogenic secondary organic aerosol tracers from aromatic hydrocarbons, Atmos. Chem. Phys., 17, 2053-2065, https://doi.org/10.5194/acp17-2053-2017, 2017.

Bahadur, R., Praveen, P. S., Xu, Y., and Ramanathan, V.: Solar absorption by elemental and brown carbon determined from spectral observations, P. Natl. Acad. Sci. USA, 109, 17366-17371, https://doi.org/10.1073/pnas.1205910109, 2012.

Bond, T. C., Zarzycki, C., Flanner, M. G., and Koch, D. M.: Quantifying immediate radiative forcing by black carbon and organic 
matter with the Specific Forcing Pulse, Atmos. Chem. Phys., 11, 1505-1525, https://doi.org/10.5194/acp-11-1505-2011, 2011.

Boulanger, Y., Gauthier, S., and Burton, P. J.: A refinement of models projecting future Canadian fire regimes using homogeneous fire regime zones, Can. J. Forest Res., 44, 365-376, https://doi.org/10.1139/cjfr-2013-0372, 2014.

Budisulistiorini, S. H., Riva, M., Williams, M., Chen, J., Itoh, M., Surratt, J. D., and Kuwata, M.: Light-absorbing brown carbon aerosol constituents from combustion of Indonesian peat and biomass, Environ. Sci. Technol., 51, 4415-4423, https://doi.org/10.1021/acs.est.7b00397, 2017.

Calvert, J. G. and Pitts, J. N.: Photochemistry, John Wiley \& Sons, Ltd, New York City, New York, USA, 1966.

Cha, E., Jeong, E. S., Han, S. B., Cha, S., Son, J., Kim, S., Oh, H. B., and Lee, J.: Ionization of gas-phase polycyclic aromatic hydrocarbons in electrospray ionization coupled with gas chromatography, Anal. Chem., 90, 4203-4211, https://doi.org/10.1021/acs.analchem.8b00401, 2018.

Chakrabarty, R. K., Moosmüller, H., Chen, L.-W. A., Lewis, K., Arnott, W. P., Mazzoleni, C., Dubey, M. K., Wold, C. E., Hao, W. M., and Kreidenweis, S. M.: Brown carbon in tar balls from smoldering biomass combustion, Atmos. Chem. Phys., 10, 63636370, https://doi.org/10.5194/acp-10-6363-2010, 2010.

Chang, J. L. and Thompson, J. E.: Characterization of colored products formed during irradiation of aqueous solutions containing $\mathrm{H} 2 \mathrm{O} 2$ and phenolic compounds, Atmos. Environ., 44, 541-551, https://doi.org/10.1016/J.ATMOSENV.2009.10.042, 2010.

Chen, Y. and Bond, T. C.: Light absorption by organic carbon from wood combustion, Atmos. Chem. Phys., 10, 1773-1787, https://doi.org/10.5194/acp-10-1773-2010, 2010.

Chung, C. E., Ramanathan, V., and Decremer, D.: Observationally constrained estimates of carbonaceous aerosol radiative forcing, P. Natl. Acad. Sci. USA, 109, 11624-11629, https://doi.org/10.1073/pnas.1203707109, 2012.

Di Lorenzo, R. A., Washenfelder, R. A., Attwood, A. R., Guo, H., Xu, L., Ng, N. L., Weber, R. J., Baumann, K., Edgerton, E., and Young, C. J.: Molecular-Size-Separated Brown Carbon Absorption for Biomass-Burning Aerosol at Multiple Field Sites, Environ. Sci. Technol., 51, 3128-3137, https://doi.org/10.1021/acs.est.6b06160, 2017.

Feng, Y., Ramanathan, V., and Kotamarthi, V. R.: Brown carbon: a significant atmospheric absorber of solar radiation?, Atmos. Chem. Phys., 13, 8607-8621, https://doi.org/10.5194/acp13-8607-2013, 2013.

Fernández, P., Grimalt, J. O., and Vilanova, R. M.: Atmospheric gas-particle partitioning of polycyclic aromatic hydrocarbons in high mountain regions of Europe, Environ. Sci. Technol., 36, 1162-1168, https://doi.org/10.1021/es010190t, 2002.

Finlayson-Pitts, B. J. and Pitts, J. N.: Chemistry of the Upper and Lower Atmosphere: Theory, Experiments, and Applications, Academic Press, San Diego, CA, USA, 2000.

Fleming, L. T., Lin, P., Laskin, A., Laskin, J., Weltman, R., Edwards, R. D., Arora, N. K., Yadav, A., Meinardi, S., Blake, D. R., Pillarisetti, A., Smith, K. R., and Nizkorodov, S. A.: Molecular composition of particulate matter emissions from dung and brushwood burning household cookstoves in Haryana, India, Atmos. Chem. Phys., 18, 2461-2480, https://doi.org/10.5194/acp18-2461-2018, 2018.
Forrister, H., Liu, J., Scheuer, E., Dibb, J., Ziemba, L., Thornhill, K. L., Anderson, B., Diskin, G., Perring, A. E., Schwarz, J. P., Campuzano-Jost, P., Day, D. A., Palm, B. B., Jimenez, J. L., Nenes, A., and Weber, R. J.: Evolution of brown carbon in wildfire plumes, Geophys. Res. Lett., 42, 4623-4630, https://doi.org/10.1002/2015GL063897, 2015.

Gelencsér, A., Hoffer, A., Kiss, G., Tombácz, E., Kurdi, R., and Bencze, L.: In-situ formation of light-absorbing organic matter in cloud water, J. Atmos. Chem., 45, 25-33, https://doi.org/10.1023/A:1024060428172, 2003.

Girotto, G., China, S., Bhandari, J., Gorkowski, K., Scarnato, B. V., Capek, T., Marinoni, A., Veghte, D. P., Kulkarni, G., Aiken, A. C., Dubey, M., and Mazzoleni, C.: Fractal-like tar ball aggregates from wildfire smoke, Environ. Sci. Technol. Lett., 5, 360-365, https://doi.org/10.1021/acs.estlett.8b00229, 2018.

Harrison, M. A. J., Barra, S., Borghesi, D., Vione, D., Arsene, C., and Iulian Olariu, R.: Nitrated phenols in the atmosphere: a review, Atmos. Environ., 39, 231-248, https://doi.org/10.1016/J.ATMOSENV.2004.09.044, 2005.

Hems, R. F. and Abbatt, J. P. D.: Aqueous Phase Photo-oxidation of brown carbon nitrophenols: Reaction kinetics, mechanism, and evolution of light absorption, ACS Earth Space Chem., 2, 225234, https://doi.org/10.1021/acsearthspacechem.7b00123, 2018.

Hinks, M. L., Brady, M. V., Lignell, H., Song, M., Grayson, J. W., Bertram, A. K., Lin, P., Laskin, A., Laskin, J., and Nizkorodov, S. A.: Effect of viscosity on photodegradation rates in complex secondary organic aerosol materials, Phys. Chem. Chem. Phys., 18, 8785-8793, https://doi.org/10.1039/C5CP05226B, 2016.

Iinuma, Y., Böge, O., Gräfe, R., and Herrmann, H.: Methylnitrocatechols: Atmospheric tracer compounds for biomass burning secondary organic aerosols, Environ. Sci. Technol., 44, 8453-8459, https://doi.org/10.1021/es102938a, 2010.

Iinuma, Y., Keywood, M., and Herrmann, H.: Characterization of primary and secondary organic aerosols in Melbourne airshed: The influence of biogenic emissions, wood smoke and bushfires, Atmos. Environ., 130, 54-63, https://doi.org/10.1016/J.ATMOSENV.2015.12.014, 2016.

Iranshahi, M., Askari, M., Sahebkar, A., and Hadjipavlou-Litina, D.: Evaluation of antioxidant, anti-inflammatory and lipoxygenase inhibitory activities of the prenylated coumarin umbelliprenin, available at: https://ikee.lib.auth.gr/record/226183/files/ Litina.pdf (last access: 21 September 2018), 2009.

Jen, C. N., Hatch, L. E., Selimovic, V., Yokelson, R. J., Weber, R., Fernandez, A. E., Kreisberg, N. M., Barsanti, K. C., and Goldstein, A. H.: Speciated and total emission factors of particulate organics from burning western US wildland fuels and their dependence on combustion efficiency, Atmos. Chem. Phys., 19, 1013-1026, https://doi.org/10.5194/acp-19-1013-2019, 2019.

Jiang, X., Wiedinmyer, C., and Carlton, A. G.: Aerosols from Fires: An examination of the effects on ozone photochemistry in the western United States, Environ. Sci. Technol., 46, 11878-11886, https://doi.org/10.1021/es301541k, 2012.

Kaur, R., Labins, J. R., Helbock, S. S., Jiang, W., Bein, K. J., Zhang, Q., and Anastasio, C.: Photooxidants from brown carbon and other chromophores in illuminated particle extracts, Atmos. Chem. Phys., 19, 6579-6594, https://doi.org/10.5194/acp19-6579-2019, 2019.

Keyte, I. J., Harrison, R. M., and Lammel, G.: Chemical reactivity and long-range transport potential of polycyclic aromatic 
hydrocarbons - a review, Chem. Soc. Rev., 42, 9333-9391, https://doi.org/10.1039/c3cs60147a, 2013.

Kirchstetter, T. W., Novakov, T., and Hobbs, P. V.: Evidence that the spectral dependence of light absorption by aerosols is affected by organic carbon, J. Geophys. Res.-Atmos., 109, D21208, https://doi.org/10.1029/2004JD004999, 2004.

Laskin, A., Laskin, J., and Nizkorodov, S. A.: Chemistry of atmospheric brown carbon, Chem. Rev., 115, 4335-4382, https://doi.org/10.1021/cr5006167, 2015.

Lee, S., Shin, D.-S., Kim, J. S., Oh, K.-B., and Kang, S. S.: Antibacterial coumarins from Angelica gigas roots, Arch. Pharm. Res., 26, 449-452, https://doi.org/10.1007/BF02976860, 2003.

Li, C., He, Q., Schade, J., Passig, J., Zimmermann, R., Meidan, D., Laskin, A., and Rudich, Y.: Dynamic changes in optical and chemical properties of tar ball aerosols by atmospheric photochemical aging, Atmos. Chem. Phys., 19, 139-163, https://doi.org/10.5194/acp-19-139-2019, 2019.

Li, G., Bei, N., Tie, X., and Molina, L. T.: Aerosol effects on the photochemistry in Mexico City during MCMA2006/MILAGRO campaign, Atmos. Chem. Phys., 11, 51695182, https://doi.org/10.5194/acp-11-5169-2011, 2011.

Li, X., Jiang, L., Hoa, L. P., Lyu, Y., Xu, T., Yang, X., Iinuma, Y., Chen, J., and Herrmann, H.: Size distribution of particle-phase sugar and nitrophenol tracers during severe urban haze episodes in Shanghai, Atmos. Environ., 145, 115-127, https://doi.org/10.1016/j.atmosenv.2016.09.030, 2016.

Lignell, H., Hinks, M. L., and Nizkorodov, S. A.: Exploring matrix effects on photochemistry of organic aerosols, P. Natl. Acad. Sci. USA, 111, 13780-5, https://doi.org/10.1073/pnas.1322106111, 2014.

Lin, P., Liu, J., Shilling, J. E., Kathmann, S. M., Laskin, J., and Laskin, A.: Molecular characterization of brown carbon (BrC) chromophores in secondary organic aerosol generated from photo-oxidation of toluene, Phys. Chem. Chem. Phys., 17, 23283-23676, https://doi.org/10.1039/c5cp02563j, 2015a.

Lin, P., Laskin, J., Nizkorodov, S. A., and Laskin, A.: Revealing brown carbon chromophores produced in reactions of methylglyoxal with ammonium sulfate, Environ. Sci. Technol., 49, 1425714266, https://doi.org/10.1021/acs.est.5b03608, 2015 b.

Lin, P., Aiona, P. K., Li, Y., Shiraiwa, M., Laskin, J., Nizkorodov, S. A., and Laskin, A.: Molecular characterization of brown carbon in biomass burning aerosol particles, Environ. Sci. Technol., 50, 11815-11824, https://doi.org/10.1021/acs.est.6b03024, 2016.

Lin, P., Bluvshtein, N., Rudich, Y., Nizkorodov, S., Laskin, J., and Laskin, A.: Molecular chemistry of atmospheric brown carbon inferred from a nationwide biomassburning event, Environ. Sci. Technol., 51, 11561-11570, https://doi.org/10.1021/acs.est.7b02276, 2017.

Lin, P., Fleming, L. T., Nizkorodov, S. A., Laskin, J., and Laskin, A.: Comprehensive molecular characterization of atmospheric brown carbon by high resolution mass spectrometry with electrospray and atmospheric pressure photoionization, Anal. Chem., 90, 12493-12502, https://doi.org/10.1021/acs.analchem.8b02177, 2018.

Ma, X., Yu, F., and Luo, G.: Aerosol direct radiative forcing based on GEOS-Chem-APM and uncertainties, Atmos. Chem. Phys., 12, 5563-5581, https://doi.org/10.5194/acp-125563-2012, 2012.
Macdonald, R. W., Barrie, L. A., Bidleman, T. F., Diamond, M. L., Gregor, D. J., Semkin, R. G., Strachan, W. M. J., Li, Y. F., Wania, F., Alaee, M., Alexeeva, L. B., Backus, S. M., Bailey, R., Bewers, J. M., Gobeil, C., Halsall, C. J., Harner, T., Hoff, J. T., Jantunen, L. M. M., Lockhart, W. L., Mackay, D., Muir, D. C. G., Pudykiewicz, J., Reimer, K. J., Smith, J. N., Stern, G., Schroeder, W. H., Wagemann, R., and Yunker, M. B.: Contaminants in the Canadian Arctic: 5 years of progress in understanding sources, occurrence and pathways, Sci. Total Environ., 254, 93-234, https://doi.org/10.1016/S0048-9697(00)00434-4, 2000.

Madronich, S., Flocke, S., Zeng, J., Petropavlovskikh, I., and Lee-Taylor, J.: Tropospheric Ultraviolet and Visible (TUV) Radiation Model, available at: http://cprm.acom.ucar.edu/Models/ TUV/Interactive_TUV/ (last access: 1 May 2019.), 2002.

Malecha, K. T. and Nizkorodov, S. A.: Feasibility of photosensitized reactions with secondary organic aerosol particles in the presence of volatile organic compounds, J. Phys. Chem. A, 121, 4961-4967, https://doi.org/10.1021/acs.jpca.7b04066, 2017.

Miller, J. S. and Olejnik, D.: Photolysis of polycyclic aromatic hydrocarbons in water, Water Res., 35, 233-243, https://doi.org/10.1016/S0043-1354(00)00230-X, 2001.

Monge, M. E., Rosenørn, T., Favez, O., Müller, M., Adler, G., Abo Riziq, A., Rudich, Y., Herrmann, H., George, C., and D'Anna, B.: Alternative pathway for atmospheric particles growth, P. Natl. Acad. Sci. USA, 109, 6840-6844, https://doi.org/10.1073/pnas.1120593109, 2012.

Moorthy, B., Chu, C., and Carlin, D. J.: Polycyclic aromatic hydrocarbons: From metabolism to lung cancer, Toxicol. Sci., 145, 5-15, https://doi.org/10.1093/toxsci/kfv040, 2015.

Moriondo, M., Good, P., Durao, R., Bindi, M., Giannakopoulos, C., and Corte-Real, J.: Potential impact of climate change on fire risk in the Mediterranean area, Clim. Res., 31, 85-95, https://doi.org/10.3354/cr031085, 2006.

Pluskal, T., Castillo, S., Villar-Briones, A., and Orešič, M.: MZmine 2: Modular framework for processing, visualizing, and analyzing mass spectrometry-based molecular profile data, BMC Bioinformatics, 11, 395, https://doi.org/10.1186/1471-2105-11-395, 2010.

Pósfai, M., Gelencsér, A., Simonics, R., Arató, K., Li, J., Hobbs, P. V., and Buseck, P. R.: Atmospheric tar balls: Particles from biomass and biofuel burning, J. Geophys. Res.-Atmos., 109, D06213, https://doi.org/10.1029/2003JD004169, 2004.

Presser, C., Conny, J. M., and Nazarian, A.: Filter material effects on particle absorption optical properties, Aerosol Sci. Tech., 48, 515-529, https://doi.org/10.1080/02786826.2014.890999, 2014.

Ramanathan, V., Li, F., Ramana, M. V., Praveen, P. S., Kim, D., Corrigan, C. E., Nguyen, H., Stone, E. A., Schauer, J. J., Carmichael, G. R., Adhikary, B., and Yoon, S. C.: Atmospheric brown clouds: Hemispherical and regional variations in long-range transport, absorption, and radiative forcing, J. Geophys. Res., 112, D22S21, https://doi.org/10.1029/2006JD008124, 2007.

Saleh, R., Hennigan, C. J., McMeeking, G. R., Chuang, W. K., Robinson, E. S., Coe, H., Donahue, N. M., and Robinson, A. L.: Absorptivity of brown carbon in fresh and photo-chemically aged biomass-burning emissions, Atmos. Chem. Phys., 13, 76837693, https://doi.org/10.5194/acp-13-7683-2013, 2013.

Sarkanen, K. V. and Ludwig, C. H.: Lignins, J. Wiley \& Sons, New York City, USA, 1971. 
Sedlacek III, A. J., Buseck, P. R., Adachi, K., Onasch, T. B., Springston, S. R., and Kleinman, L.: Formation and evolution of tar balls from northwestern US wildfires, Atmos. Chem. Phys., 18, 11289-11301, https://doi.org/10.5194/acp-18-112892018, 2018.

Selimovic, V., Yokelson, R. J., Warneke, C., Roberts, J. M., de Gouw, J., Reardon, J., and Griffith, D. W. T.: Aerosol optical properties and trace gas emissions by PAX and OP-FTIR for laboratory-simulated western US wildfires during FIREX, Atmos. Chem. Phys., 18, 2929-2948, https://doi.org/10.5194/acp18-2929-2018, 2018.

Selimovic, V., Yokelson, R. J., McMeeking, G. R., and Coefield, S.: In situ measurements of trace gases, PM, and aerosol optical properties during the 2017 NW US wildfire smoke event, Atmos. Chem. Phys., 19, 3905-3926, https://doi.org/10.5194/acp19-3905-2019, 2019.

Shankar, R., An, J. G., Loh, A., and Yim, U. H.: A systematic study of the effects of solvents on phenanthrene photooxidation, Chemosphere, 220, 900-909, https://doi.org/10.1016/J.CHEMOSPHERE.2018.12.206, 2019.

Shvidenko, A. Z. and Schepaschenko, D. G.: Climate change and wildfires in Russia, Contemp. Probl. Ecol., 6, 683-692, https://doi.org/10.1134/S199542551307010X, 2013.

Simoneit, B. R. T.: Biomass burning - a review of organic tracers for smoke from incomplete combustion, Appl. Geochem., 17, 129162, https://doi.org/10.1016/S0883-2927(01)00061-0, 2002.

Simoneit, B. R. T., Rogge, W. F., Mazurek, M. A., Standley, L. J., Hildemann, L. M., and Cass, G. R.: Lignin pyrolysis products, lignans, and resin acids as specific tracers of plant classes in emissions from biomass combustion, Environ. Sci. Technol., 27, 2533-2541, https://doi.org/10.1021/es00048a034, 1993.

Smith, J. D., Kinney, H., and Anastasio, C.: Phenolic carbonyls undergo rapid aqueous photodegradation to form lowvolatility, light-absorbing products, Atmos. Environ., 126, 3644, https://doi.org/10.1016/J.ATMOSENV.2015.11.035, 2016.

Smol, M. and Włodarczyk-Makuła, M.: The Effectiveness in the Removal of PAHs from Aqueous Solutions in Physical and Chemical Processes: A Review, Polycycl. Aromat. Comp., 37, 292-313, https://doi.org/10.1080/10406638.2015.1105828, 2017.

Sofowote, U. M., Hung, H., Rastogi, A. K., Westgate, J. N., Deluca, P. F., Su, Y., and McCarry, B. E.: Assessing the long-range transport of $\mathrm{PAH}$ to a sub-Arctic site using positive matrix factorization and potential source contribution function, Atmos. Environ., 45, 967-976, https://doi.org/10.1016/J.ATMOSENV.2010.11.005, 2011.

Sumlin, B. J., Pandey, A., Walker, M. J., Pattison, R. S., Williams, B. J., and Chakrabarty, R. K.: Atmospheric Photooxidation Diminishes Light Absorption by Primary Brown Carbon Aerosol from Biomass Burning, Environ. Sci. Technol. Lett., 4, 540-545, https://doi.org/10.1021/acs.estlett.7b00393, 2017.

Surawski, N. C., Sullivan, A. L., Meyer, C. P., Roxburgh, S. H., and Polglase, P. J.: Greenhouse gas emissions from laboratoryscale fires in wildland fuels depend on fire spread mode and phase of combustion, Atmos. Chem. Phys., 15, 5259-5273, https://doi.org/10.5194/acp-15-5259-2015, 2015.

Tang, H. and Thompson, J. E.: Light-Absorbing Products Form during the Aqueous Phase Reaction of Phenolic Compounds in the
Presence of Nitrate and Nitrite with UV Illumination, Open J. Air Pollut., 1, 13-21, https://doi.org/10.4236/ojap.2012.12002, 2012.

Tihay-Felicelli, V., Santoni, P. A., Gerandi, G., and Barboni, T.: Smoke emissions due to burning of green waste in the Mediterranean area: Influence of fuel moisture content and fuel mass, Atmos. Environ., 159, 92-106, https://doi.org/10.1016/J.ATMOSENV.2017.04.002, 2017.

Tomaz, S., Cui, T., Chen, Y., Sexton, K. G., Roberts, J. M., Warneke, C., Yokelson, R. J., Surratt, J. D., and Turpin, B. J.: Photochemical cloud processing of primary wildfire emissions as a potential source of secondary organic aerosol, Environ. Sci. Technol., 52, 11027-11037, https://doi.org/10.1021/acs.est.8b03293, 2018.

Tóth, A., Hoffer, A., Nyirő-Kósa, I., Pósfai, M., and Gelencsér, A.: Atmospheric tar balls: aged primary droplets from biomass burning?, Atmos. Chem. Phys., 14, 6669-6675, https://doi.org/10.5194/acp-14-6669-2014, 2014.

Turro, N. J., Ramamurthy, V., and Scaiano, J. C.: Modern molecular photochemistry of organic molecules, University Science Books, Sausalito, CA, USA, 2009.

Venugopala, K. N., Rashmi, V., and Odhav, B.: Review on natural coumarin lead compounds for their pharmacological activity, Biomed Res. Int., 2013, 963248, https://doi.org/10.1155/2013/963248, 2013.

Wang, Y., Liang, H., Zhang, Q., Cheng, W., and Yi, S.: Phytochemical and chemotaxonomic study on Ficus tsiangii Merr. ex Corner, Biochem. Syst. Ecol., 57, 210-215, https://doi.org/10.1016/j.bse.2014.08.003, 2014.

Weber, M. G. and Stocks, B. J.: Forest fires and sustainability in the boreal forests of Canada, Ambio, 27, 545-550, available at: https://cfs.nrcan.gc.ca/publications?id=9899 (last access: 25 January 2020), 1998.

Wong, J. P. S., Nenes, A., and Weber, R. J.: Changes in light absorptivity of molecular weight separated brown carbon due to photolytic aging, Environ. Sci. Technol., 51, 8414-8421, https://doi.org/10.1021/acs.est.7b01739, 2017.

Wood, A. W., Chang, R. L., Levin, W., Thakker, D. R., Yagi, H., Sayer, J. M., Jerina, D. M., and Conney, A. H.: Mutagenicity of the enantiomers of the diastereomeric bay-region benzo(c)phenanthrene 3,4-diol-1,2-epoxides in bacterial and mammalian cells, available at: http://cancerres.aacrjournals.org/ content/44/6/2320.full-text.pdf (last access: 28 September 2018), 1984.

Wotton, B. M. and Flannigan, M. D.: Length of the fire season in a changing climate, Forest. Chron., 69, 187-192, https://doi.org/10.5558/tfc69187-2, 1993.

Wotton, B. M., Nock, C. A., and Flannigan, M. D.: Forest fire occurrence and climate change in Canada, Int. J. Wildl. Fire, 19, 253-271, https://doi.org/10.1071/WF09002, 2010.

Xie, M., Chen, X., Hays, M. D., and Holder, A. L.: Composition and light absorption of $\mathrm{N}$-containing aromatic compounds in organic aerosols from laboratory biomass burning, Atmos. Chem. Phys., 19, 2899-2915, https://doi.org/10.5194/acp-192899-2019, 2019.

Xue, W. and Warshawsky, D.: Metabolic activation of polycyclic and heterocyclic aromatic hydrocarbons and DNA damage: A review, Toxicol. Appl. Pharmacol., 206, 73-93, https://doi.org/10.1016/J.TAAP.2004.11.006, 2005. 
Zhao, R., Lee, A. K. Y., Huang, L., Li, X., Yang, F., and Abbatt, J. P. D.: Photochemical processing of aqueous atmospheric brown carbon, Atmos. Chem. Phys., 15, 6087-6100, https://doi.org/10.5194/acp-15-6087-2015, 2015.

Zhong, M. and Jang, M.: Dynamic light absorption of biomass-burning organic carbon photochemically aged under natural sunlight, Atmos. Chem. Phys., 14, 1517-1525, https://doi.org/10.5194/acp-14-1517-2014, 2014.

Zhou, S., Lee, A. K. Y., McWhinney, R. D., and Abbatt, J. P. D.: Burial effects of organic coatings on the heterogeneous reactivity of particle-borne benzo[a]pyrene (BaP) toward ozone, J. Phys. Chem. A, 116, 7050-7056, https://doi.org/10.1021/jp3030705, 2012.
Zhou, S., Yeung, L. W. Y., Forbes, M. W., Mabury, S., and Abbatt, J. P. D.: Epoxide formation from heterogeneous oxidation of benzo[a]pyrene with gas-phase ozone and indoor air, Environ. Sci. Process. Impacts, 19, 1292-1299, https://doi.org/10.1039/c7em00181a, 2017.

Zhou, S., Hwang, B. C. H., Lakey, P. S. J., Zuend, A., Abbatt, J. P. D., and Shiraiwa, M.: Multiphase reactivity of polycyclic aromatic hydrocarbons is driven by phase separation and diffusion limitations, P. Natl. Acad. Sci. USA, 116, 11658-11663, https://doi.org/10.1073/pnas.1902517116, 2019. 